\title{
OCORRÊNCIA DE RESÍDUOS DE ANTIMICROBIANOS UTILIZADOS NO TRATAMENTO DE INTERRUPÇÃO DE LACTAÇÃO NO INÍCIO DA LACTAÇÃO SUBSEQUENTE EM ANIMAIS COM PERÍODO SECO RECOMENDADO
}

\section{Helena Fagundes}

Dissertação de Mestrado depositada na Seção de Pós-Graduação da Faculdade de Zootecnia e Engenharia de Alimentos da USP, como parte dos requisitos para a obtenção do Título de Mestre em Zootecnia, na área de Concentração: Qualidade e Produtividade Animal.

Orientador: Prof.Dra. Elizabeth Oliveira da Costa Freitas Guimarães 
"Ser científico não significa ser infalível, mas ser prático e de boa fé e tão honesto quanto possamos ser". 
"Fruto de enganos ou de amores, Nasço de minha própria contradição.

O contorno da boca, A forma das mãos, o jeito de andar... (sonhos e temores incluídos) virão desses que me formaram. Mas o que eu traçar no espelho, há de se armar também segundo o meu desejo. Terei meu par de asas cujo o vôo se levanta desses, que me dão a sombra onde eu cresço - como, debaixo da árvore, um caule e sua flor". (Lya Luft)

Dedico este Trabalho:

Aos meus pais, Leora e Renato, e a minha irmã Laura, pelo amor incondicional, pelo apoio e pela forma de encarar a vida: sempre de frente, sem esmaecer! 
"O amor não consiste em olhar um para o outro, mas sim em olhar juntos para a mesma direção". (Antoine de Saint-Exupéry)

Ofereço este Trabalho:

Ao Ico, por compartilhar dos "mesmos sonhos e desejos", pelo incentivo e por ser o meu porto seguro nesta importante etapa da minha vida. 


\section{AGRADECIMENTOS}

A Deus por continuar me auxiliando a encontrar o caminho certo.

A minha Orientadora Professora Elizabeth Oliveira da Costa, pela competência, forma determinada de ser, apoio e ensinamentos ao longo desses dois anos.

Aos meus Tios Breno e Alcidia. Vocês foram realmente muito importantes nesta minha conquista. Obrigada por acreditarem e confiarem em mim. Amo muito vocês...E vou amar sempre, esteja eu onde estiver.

A Liane, pelo carinho, dedicação e exemplo de luta.

A minha querida amiga Luciane, pelas infindáveis conversas e apoio... As amigas Fernanda (Rot) e Andrezza, pela amizade e boas risadas... Aos demais amigos: Chorão, Maurício, Minhoca, Luiz, Amaury, Laurinha, Érica, Sal, (...) "O encanto da vida depende unicamente das boas amizades que cultivamos".(Malba Taham).

Aos amigos conterrâneos, Bugio, Saulo, Evelise e Isabelle por fazerem eu me sentir um pouquinho mais perto do Rio Grande, minha terra querida!

As minhas irmãs de coração Teca e Paty, pela eterna amizade.

Aos colegas do NAPGAMA, Felício, Viviane, Cláudia, Eliza, Roberto e aos funcionários Fátima e Marcos pelas incontáveis colaborações.

Aos pesquisadores e amigos Juliana e Irineu Arcaro e Cláudia Pozzi, pelo apoio e amizade na construção desse projeto. A ajuda de vocês foi fundamental para que eu aqui chegasse. 
As propriedades e aos proprietários, pela receptividade e cordialidade. Ao amigo e colega Ricardo pelas infinitas "ajudinhas"...Aos funcionários Tolina, Tonho, Lúcia, Rodrigo e Beco; e ao Veterinário Carlos pela disposição e auxílio em todos os momentos.

Ao Professor Edison Schalch, pela amizade, apoio e contribuição neste trabalho.

A CAPES, pelo auxílio financeiro da bolsa institucional.

A Faculdade de Zootecnia e Engenharia de Alimentos, FZEA/USP pelas oportunidades e apoio na realização deste projeto.

E a todos, que de alguma maneira participaram da construção desse caminho, ficam os versos de um grande amigo: "Quem traz em si o caminho que é novo a cada momento, tem na inconstância do vento o destino que lhe cabe. Nem mesmo o destino sabe do porque destas partidas, das múltiplas despedidas que o tempo nos apresenta..." (Gujo Teixeira). 


\section{SUMÁRIO}

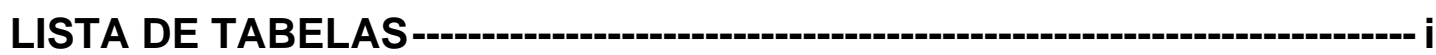

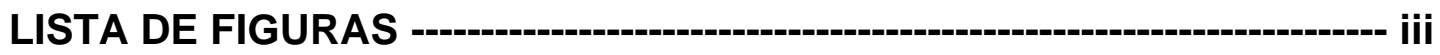

LISTA DE ABREVIATURAS E SIGLAS ---

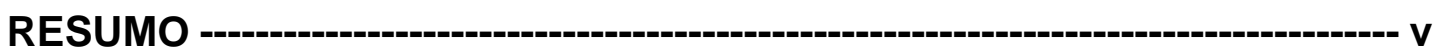

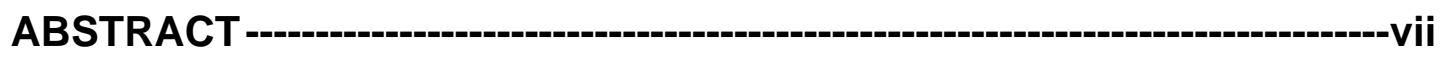

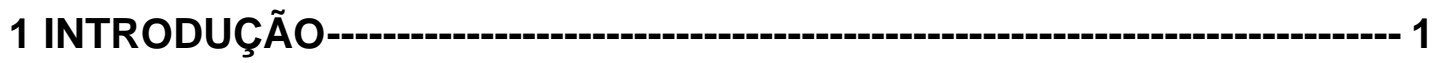

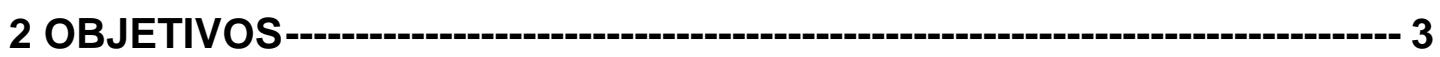

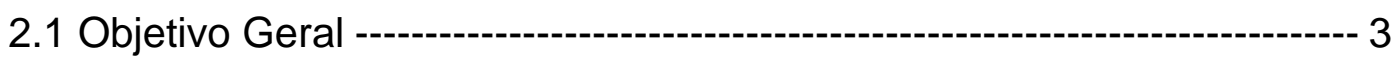

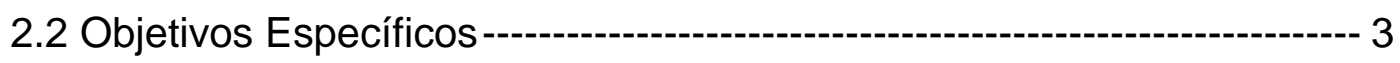

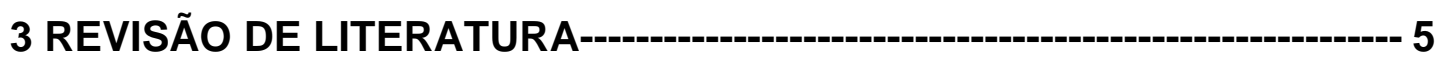

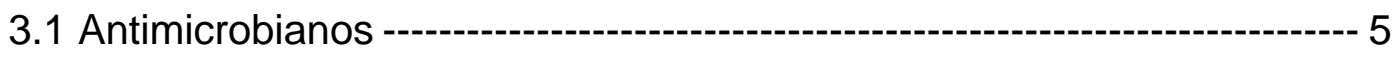

3.2 Mastite---------------------------------------------------------------------------------- 6

3.3 Medidas terapêuticas para controle da mastite ------------------------------ 7

3.4 Período Seco e Lactação Subseqüente --------------------------------------- 9

3.5 Tratamento intramamário na interrupção da lactação---------------------11

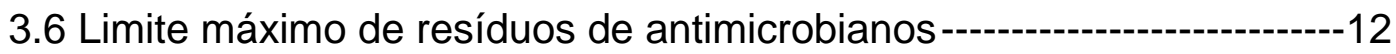

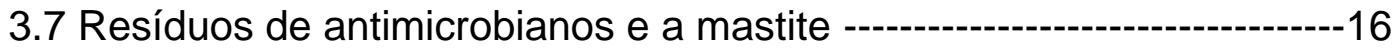

3.8 Presença de resíduos de antimicrobianos no leite e os riscos à saúde

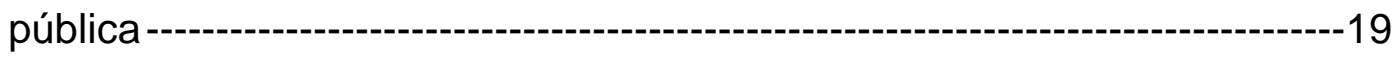

3.9 Testes de detecção de resíduos de antimicrobianos no leite-------------21

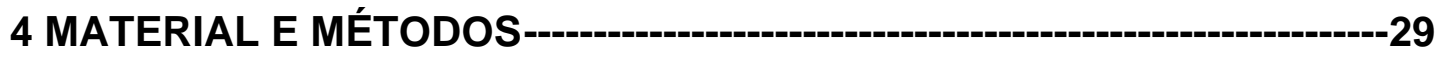

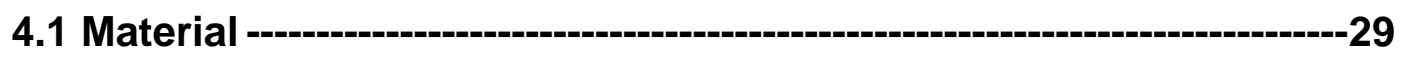

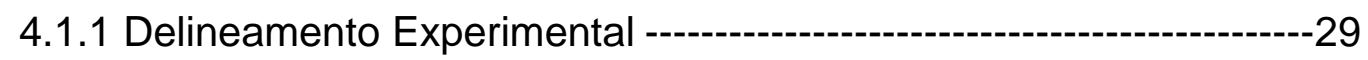




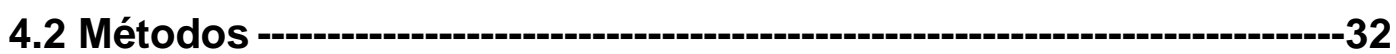

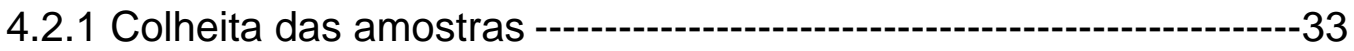

4.2.2 Diagnóstico do processo inflamatório ----------------------------------33

4.2.3 Identificação dos agentes causais da mastite --------------------------35

4.2.4 Detecção de resíduos de antimicrobianos -----------------------------35

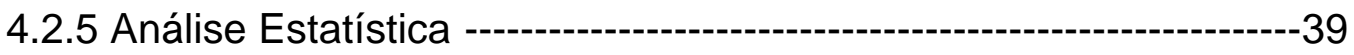

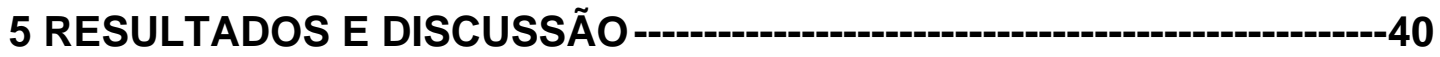

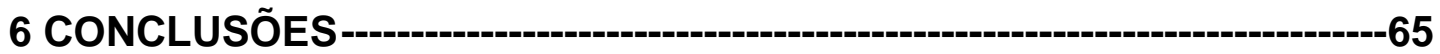

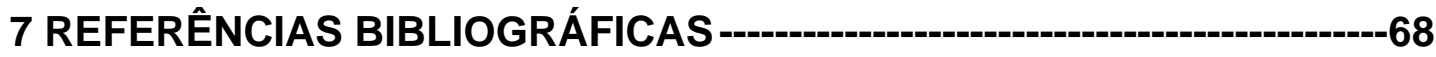




\section{LISTA DE TABELAS}

Tabela 1 - Limite Máximo permitido de resíduos de antimicrobianos no leite $(\mathrm{mg} / \mathrm{Kg})$, de acordo com a Comissão do Codex Alimentarius (CODEX), Food and Drug Administration (EUA), União Européia e Ministério da Agricultura, Pecuária e Abastecimento (MAPA).... 15

Tabela 2 - Kits para detecção de resíduos de antibióticos no leite disponíveis no mercado.

Tabela 3 - Limites de sensibilidade (em $\mu \mathrm{g} / \mathrm{Kg}$ ) de diferentes testes de inibição do crescimento microbiano para diferentes antimicrobianos. 24

Tabela 4 - Características das propriedades leiteiras. Pirassununga, São Paulo. 2003 30

Tabela 5 - Características de manejo, higiene de ordenha e medidas de prevenção de mastite das propriedades. Estado de São Paulo. 2003 31

Tabela 6 - Rotina de Tratamentos de mastite: medicamentos habitualmente utilizados. Estado de São Paulo. 2003 31

Tabela 7 - Avaliação da influência do tipo de medicamento utilizado na secagem, na ocorrência de resíduos de antimicrobianos no leite. Pirassununga, São Paulo. 2003 43

Tabela 8 - Avaliação quanto à influência da duração do período seco na ocorrência de resíduos de antimicrobianos no leite referentes à Propriedade A. Pirassununga, São Paulo. 2003. 45

Tabela 9 - Avaliação da duração do período seco (dias) em relação aos grupos farmacológicos utilizados no tratamento de secagem. Pirassununga, São Paulo. 2003 49

Tabela 10 - Influência do volume de produção de leite média durante a lactação e a produção no dia da secagem na ocorrência de 
resíduos de antimicrobianos na Propriedade A. Pirassununga, São Paulo. 2003 50

Tabela 11 - Influência da duração do período seco em relação ao volume de produção de leite na secagem na ocorrência de resíduos de antimicrobianos no leite. Pirassununga, São Paulo. 2003. 52

Tabela 12 - Avaliação da influência da ocorrência e intensidade do processo inflamatório na presença de resíduos de antimicrobianos no leite na propriedade A. Pirassununga, São Paulo. 2003 52

Tabela 13 - Influência da presença infecção no período pós-parto na ocorrência de resíduos detectáveis de antimicrobianos no leite. Pirassununga, São Paulo. 2003 54

Tabela 14 - Influência do intervalo de tempo entre tratamento e colheita das amostras (ITC) na ocorrência de resíduos de antimicrobianos na Propriedade A e C. Pirassununga, São Paulo. 2003 56

Tabela 15 - Número de quartos com resíduo positivo para antimicrobianos por animal na propriedade A. Pirassununga, São Paulo. 2003 ... 57

Tabela 16 - Número de quartos com resíduo positivo para antimicrobianos por animal na propriedade A. Pirassununga, São Paulo. 2003 ... 58

Tabela 17 - Análise custo: benefício relacionando a utilização do período mínimo de descarte (71 dias) e a utilização do teste de triagem (Delvotest ${ }^{\circledR}$ SP). Pirassununga, São Paulo. 2003 62 


\section{LISTA DE FIGURAS}

Figura 1 - Teste microbiológico comercial Delvotest ${ }^{\circledR} \mathrm{SP}$ utilizado no experimento para detectar resíduo de antimicrobianos no leite. Pirassununga, São Paulo. 2003 $-36$

Figura 2 - Adição de 0,1 mililitros da amostra de leite na ampola já contendo a pastilha nutriente de glicose. Pirassununga, São Paulo. 2003

Figura 3 - Realização da leitura das amostras após a incubação no banho Maria por duas horas e cinqüenta minutos. Pirassununga, São Paulo. 2003 $-38$

Figura 4 - Porcentagem de glândulas mamárias positivas e negativas para a presença de resíduos de antimicrobianos, encontrada em cada propriedade avaliada. Pirassununga, São Paulo. 2003 $-44$

Figura 5 - Porcentagem de quartos avaliados na pré-secagem e no pósparto, positivos e negativos para a presença de infecção intramamária. Pirassununga, São Paulo. 2003 $-54$

Figura 6 - Porcentagem de animais positivos para resíduo de antimicrobianos de acordo com o número de quartos mamários. Pirassununga, São Paulo. 2003 $-59$ 


\section{LISTA DE ABREVIATURAS E SIGLAS}

$\mu \mathrm{g} / \mathrm{Kg}$ : microgramas por quilo

AOAC: Association of Official Analytical Chemist

CCS: Contagem de células somáticas

CMT: "California Mastitis Test"

DPC: Dias parto colheita das amostras

FAO: Food and Agricultural Organization of the United Nations

FDA: Food and Drug Administration

HPLC: Cromatografia Liquida de Alto Desempenho

IDA: Ingestão diária aceitável

IIM: Infecções intramamárias

ITC: Intervalo tratamento colheita das amostras de leite

ITL: Intervalo tratamento limpeza do leite (período de colostro)

Kg: quilogramas de leite

LMR: Limite máximo de resíduo de antimicrobianos

MAPA: Ministério da Agricultura Pecuária e Abastecimento

$\mathrm{mg} / \mathrm{Kg}$ : Miligramas por quilo

OMS: Organização Mundial da Saúde

PCRL: Programa de Controle de Resíduos no leite

PNMQL: Programa Nacional de Melhoria da Qualidade do Leite.

PS: Período seco

Quartos R +: Quartos mamários positivos para resíduo de antimicrobianos

Quartos: Quartos mamários

TTC: Método do cloreto 2-3-5-trifenil tetrazólio. 
FAGUNDES, H. OCORRÊNCIA DE RESÍDUOS DE ANTIMICROBIANOS UTILIZADOS NO TRATAMENTO DE INTERRUPÇÃO DE LACTAÇÃO NO INÍCIO DA LACTAÇÃO SUBSEQÜENTE EM ANIMAIS COM PERÍODO SECO RECOMENDADO. Pirassununga, 2003. 76 p. Dissertação (Mestrado) - Faculdade de Zootecnia e Engenharia de Alimentos, Universidade de São Paulo.

\section{RESUMO}

O objetivo do trabalho foi avaliar a ocorrência de resíduos de antimicrobianos (RA) no leite no pós-parto (PP) de vacas leiteiras tratadas no período seco (PS). Utilizou-se 74 animais distribuídos em 3 grupos: (1) $0,25 \mathrm{~g}$ de cefalônio anidro, (2) $100 \mathrm{mg}$ de hidroiodeto de penetamato +280 $\mathrm{mg}$ de penicilina benetamina $+100 \mathrm{mg}$ de sulfato de framicetina, (3) 297,92 $\mathrm{mg}$ de benzilpenicilina procaína $+121,95 \mathrm{mg}$ de monoidrato sódico de nafcilina $+34,23 \mathrm{mg}$ de sulfato de diidroestreptomicina. Na secagem realizaram-se os testes de CMT e Tamis e foram colhidas amostras para exame microbiológico. No PP realizou-se o mesmo procedimento além da colheita das amostras para RA. Para análise dos RA utilizou-se o Delvotest ${ }^{\circledR} \mathrm{SP}$. A ocorrência de RA no leite dos quartos mamários (QM) de animais tratados na secagem nas propriedades A, B e C foi: $18 \%, 22,2 \%$ e $26,5 \%$, com média de $19,4 \%$. A ocorrência de RA foi maior, quando o PS foi menor que 60 dias $(P<0,0015)$ e quando o intervalo tratamento colheita (ITC) foi menor que 70 dias $(P<0,0189)$. Os resultados evidenciaram que a presença de RA no leite ocorreu predominantemente em todos os QM e em pelo menos três deles, aumentando a possibilidade de contaminação dos tanques de pequena mistura. Não foi detectada diferença estatística quanto aos medicamentos utilizados, produção na secagem, produção na lactação, presença de processo inflamatório e infecção intramamária. O PS preconizado como ideal por proporcionar à glândula mamária tempo necessário para involução, colostrogênese e nova lactação (60 dias), não constitui garantia de isenção de RA no leite no PP, uma vez que, 19,4\% dos QM tratados na secagem, com PS entre 60 a 70 dias, apresentaram RA no 
leite. E ao ser realizada a análise custo: benefício verificou-se que a utilização do teste de triagem antes da liberação do leite para consumo, comparado ao descarte de leite, mostrou-se economicamente mais interessante.

PALAVRAS CHAVES: resíduos, antimicrobianos, Delvotest ${ }^{\circledR}$ SP, período seco, vaca seca, qualidade, leite. 


\title{
FAGUNDES, H. OCURRENCE OF ANTIMICROBIALS RESIDUES USED IN DRY COW THERAPY IN THE SUBSEQUENT LACTATION IN COWS WITH RECOMENDED DRY PERIOD.
}

\begin{abstract}
The aim of this study was to evaluate the occurrence of antimicrobials residues (AR) used in dry cow therapy, in the postpartum (PP) milk of dairy cows. Seventy-four animals were assigned in 3 groups: (1) 0,25 g de cefalônio anidro, (2) $100 \mathrm{mg}$ de hidroiodeto de penetamato $+280 \mathrm{mg}$ de penicilina benetamina + $100 \mathrm{mg}$ de sulfato de framicetina, (3) $297,92 \mathrm{mg}$ de benzilpenicilina procaína $+121,95 \mathrm{mg}$ de monoidrato sódico de nafcilina $+34,23$ $\mathrm{mg}$ de sulfato de diidroestreptomicina). Stripcup and CMT exams were carried out, either at the drying off and PP. Milk samples for microbiological examination were collected in both periods. In the PP, milk samples were collected to evaluated the occurrence of AR. Samples were screened for AR using Delvotest ${ }^{\circledR} S P$. The occurrence of $A R$ in milk of mammary quarters (MQ) treated at drying off in farms A, B and C were 18\%, 22.2\% and $26.5 \%$ respectively, with $19,4 \%$ average. The AR occurrence was higher when the dry period (DP) was less than 60 days $(P<0,0015)$ and when postpartum sampling Interval $(P S I)$ was less than 70 days $(P<0,0189)$. The results showed that $A R$ in milk, due to drying therapy, predominantly occurred in all $\mathrm{MQ}$ and in at least three of them, increasing the possibility of contamination of bulk tanks. It was not detected any statistical difference in relation to: the antibiotics used, production at drying off, milk production during lactation, and presence of inflammatory process and intramammary infection. The DP praised as ideal for providing the mammary gland time to involution, colostrogenesis and new lactation (60 days), does not constitute guarantee for AR absence in milk in PP, when 19,4\% of the MQ with DP between 60 to 70 days, had presented AR in milk. A cost: benefit analysis verified that the use of the test was useful and was economically more interesting compared with a longer period of milk discarding.
\end{abstract}

KEY WORDS: antimicrobials residues, drying off therapy, milk quality, postpartum milk, dairy cows, Delvotest ${ }^{\circledR} \mathrm{SP}$. 


\section{INTRODUÇÃO}

O leite e seus derivados desempenham um papel fundamental na nutrição dos seres humanos. É um alimento rico em proteínas, carboidratos, gorduras, sais minerais e água. Sabe-se que um litro de leite, por dia, supre todas as necessidades protéicas de crianças com até seis anos de idade, mais de $60 \%$ das necessidades protéicas dos adolescentes e $50 \%$ das necessidades protéicas dos adultos. Em relação ao cálcio, o consumo de um litro de leite supre $100 \%$ das necessidades diárias desse mineral (COSTA et al., 1996).

A questão da "qualidade e segurança" do leite e seus derivados têm recebido grande atenção por parte das autoridades, indústrias, profissionais envolvidos, produtores e consumidores. A legislação brasileira que trata especificamente desse assunto passou por um recente processo de modernização, através da criação da Portaria 51, para acompanhar as tendências mundiais e trazer melhorias ao setor.

Desde 1950, existe a preocupação da Organização Mundial da Saúde (OMS) com relação à presença de substâncias químicas nos alimentos. Atualmente, diversas organizações internacionais estão envolvidas no desenvolvimento de mecanismos de controle dessas substâncias (antibióticos, hormônios, pesticidas e parasiticidas) usadas na produção animal. Esses mecanismos incluem o controle da distribuição e uso em animais, a determinação de níveis seguros de resíduos nos alimentos de origem animal e as tecnologias de detecção de resíduos (BRITO, 2003). 
No Brasil, a prática de monitoramento de resíduos de antimicrobianos no leite está em implementação em algumas regiões, porém, ainda não atingiu níveis necessários para um controle que garanta a qualidade da matéria prima para o consumo e a manufatura dos derivados.

O uso de antibióticos na produção leiteira e os erros com 0 período de descarte são as causas mais comuns de aparecimento de resíduos de antimicrobianos no leite. Desta forma, torna-se importantíssimo à detecção desses medicamentos no leite dos animais eventualmente tratados.

Os antibióticos em Medicina Veterinária são usados com diversos fins, porém são mais freqüentemente utilizados no tratamento de mastite. $A$ mastite, segundo PHILPOT (2002), é a doença mais comum que requer terapia com antibióticos para seu controle. Está bem estabelecido que quanto menor o índice de mastite do rebanho menor a freqüência de resíduos no leite. Portanto, a melhor estratégia para reduzir o risco de resíduo de antibiótico no leite é a redução dos índices de mastite nos rebanhos.

A mastite, processo inflamatório da glândula mamária, ocorre, freqüentemente, durante o período seco e início da lactação. A prática da terapia da vaca seca tem reduzido tanto o número de infecções préexistentes e casos de mastites subclínicas, como o número de novas infecções, apresentando ação curativa e preventiva.

Desta forma o objetivo deste estudo foi avaliar, no período pósparto de vacas leiteiras, a ocorrência de resíduos de antimicrobianos utilizados no tratamento de vacas secas e, de certa forma, contribuir para o esclarecimento de alguns fatores de risco que possam estar interferindo na excreção desses medicamentos no leite. 


\section{OBJETIVOS}

\subsection{Objetivo Geral}

Avaliar, no início da lactação subseqüente, a ocorrência de resíduos de antimicrobianos utilizados no tratamento de interrupção de lactação, em animais com período seco médio de 60 dias.

\subsection{Objetivos Específicos}

i. Avaliar a influência do tipo de medicamento utilizado na secagem sobre a ocorrência de resíduos de antimicrobianos no leite.

ii. Avaliar a influência da duração do período seco sobre a ocorrência de resíduos de antimicrobianos no leite.

iii. Avaliar a influência da duração do período seco (dias) em relação aos grupos de tratamento sobre a ocorrência de resíduos de antimicrobianos no leite.

iv. Avaliar a influência do volume de produção de leite na secagem e a produção de leite na lactação sobre a ocorrência de resíduos de antimicrobianos no leite.

v. Avaliar a influência do intervalo de tempo entre tratamento e colheita das amostras sobre a ocorrência de resíduos de antimicrobianos no leite. 
vi. Avaliar a influência da ocorrência e da intensidade do processo inflamatório sobre a presença de resíduos detectáveis de antimicrobianos no leite.

vii. Avaliar a influência da presença de infecção na glândula mamária sobre a ocorrência de resíduos detectáveis de antimicrobianos no leite.

viii. Avaliar o número de quartos mamários que apresentam resíduo de antimicrobianos detectáveis (positivo) por animal tratado. 


\section{REVISÃO DE LITERATURA}

\subsection{Antimicrobianos}

Os antimicrobianos são substâncias químicas inespecíficas ou específicas que atuam sobre os microrganismos em geral, quer sejam eles patogênicos ou não. Pertencem ao primeiro grupo os desinfetantes e antisépticos, ao segundo, os quimioterápicos e antibióticos (SPINOSA, 2002).

Quimioterápicos são substâncias sintetizadas em laboratório e, antibióticos são substâncias produzidas parcial ou totalmente por seres vivos, em sua maioria fungos do gênero Streptomyces e alguns do gênero Penicillium e Cephalosporium (ALTERTHUM, 1999). Porém, na prática, esta distinção nem sempre é observada (TORTORRA et al., 2000).

O uso de antimicrobianos em animais sempre acompanhou o desenvolvimento e a utilização destes em medicina humana. Na década de 50, descobriu-se seu uso como aditivo alimentar, aumentando o crescimento animal e a eficiência produtiva (MITCHELL et al., 1998).

Os antimicrobianos mais comumente utilizados em animais de produção podem ser divididos em cinco classes incluindo os $\beta$-lactâmicos (penicilinas e cefalosporinas), as tetraciclinas (oxitetraciclina, tetraciclina e clortetraciclina), os aminoglicosídeos (estreptomicina, neomicina e gentamicina), os macrolídeos (eritromicina) e as sulfonamidas (sulfametazina) (MITCHELL et al., 1998). 


\subsection{Mastite}

A mastite é o processo inflamatório da glândula mamária que afeta, qualitativa e quantitativamente, a produção de leite. Observa-se um menor teor de lactose, caseína, gordura, cálcio e fósforo e um aumento nas imunoglobulinas, cloretos e lipases, sendo a última responsável pela rancificação do leite. Com estas alterações, o leite torna-se inadequado para o consumo e para a produção de derivados (COSTA, 1998).

Em levantamento realizado nos estados de São Paulo e Minas Gerais, o índice de prevalência de mastite clínica foi de $17,45 \%$ e de $46 \%$ para a mastite subclínica. De todos os animais examinados, $72 \%$ apresentaram pelo menos um quarto afetado (COSTA et al., 1995a). Considerando que a mastite subclínica reduz em 3\% a 4\% a produção de leite no quarto afetado, pode-se observar que estes rebanhos perderam em média cerca de $12 \%$ da produção de leite, em decorrência da mastite.

SMITH (1994) relatou que a mastite é a síndrome patológica mais comum em vacas leiteiras adultas, respondendo por $38 \%$ de toda a morbidade do rebanho. De acordo com o autor, três em cada 10 vacas leiteiras apresentam inflamação clinicamente aparente; 7\% dos animais afetados são descartados e 1\% morre em conseqüência da doença.

Segundo COSTA (1991), a mastite pode ter origem fisiológica, traumática, alérgica, metabólica ou infecciosa. Assume maior importância a mastite de origem infecciosa, que, em muitos casos, pode acarretar perda da atividade funcional da glândula, quando não forem instituídas medidas de controle e tratamento imediato, além de representar importante problema de saúde pública (BLOOD \& HENDERSON, 1978; RADOSTITS et al., 1994b).

A mastite clínica pode apresentar desde alguns coágulos, até soro com aglomerados de fibrina na secreção. A mastite classificada como subclínica, caracteriza-se pela diminuição da produção leiteira sem que, 
contudo se observem sinais de processo inflamatório ou fibrosamento (COSTA, 1998).

Os microrganismos causadores de mastite infecciosa podem ser classificados, segundo a forma de transmissão, em contagiosos e ambientais. Os microrganismos contagiosos são aqueles que colonizam o úbere e são transmitidos durante a ordenha (Staphylococcus aureus, Streptococcus agalactiae e Corynebacterium bovis). Os microrganismos ambientais, de maneira geral, podem infectar a glândula mamária através do solo, dos equipamentos de ordenha, das instalações, entre outros (SANDHOLM et al., 1990).

\subsection{Medidas terapêuticas para controle da mastite}

O princípio mais importante para o controle da mastite, segundo NICKERSON (2002), é a prevenção de infecções intramamárias. No entanto, novos casos de mastite sempre irão ocorrer e, uma vez que a infecção tenha se estabelecido, existem quatro formas de eliminação da doença. Elas incluem a cura espontânea, o descarte, o tratamento durante a lactação e o tratamento de vaca seca.

As metas da antibioticoterapia no tratamento da mastite são: a prevenção da mortalidade nos casos hiperagudos, o retorno da composição/produção normal do leite, a eliminação das fontes dos microrganismos infecciosos e a prevenção de novas infecções no período seco.

O uso de antimicrobianos intramamários em vacas no final da lactação aplicado em dose única na última esgota, vem se constituindo num eficiente método no controle da mastite (WATANABE, 1999).

Segundo NICKERSON et al., (1999), o tratamento das infecções intramamárias no momento da secagem é mais vantajoso que o tratamento 
durante a lactação, pois uma maior concentração de antibiótico é utilizado com segurança, o tempo de retenção é maior, o índice de cura também é maior e o risco da presença de resíduos é reduzido, além disso, a incidência de novas infecções durante o período não lactacional e o índice de mastite clínica no início da próxima lactação é menor.

A terapia intramamária durante a lactação, segundo NICKERSON et al., (1999), é considerada de baixa eficácia. Existem várias razões para falhas no tratamento incluindo: pobre penetração do antibiótico nos locais de fibrose, inflamação e microabcessos, inativação dos antibióticos pelo leite e seus componentes séricos, localização intracelular e sobrevivência de microrganismos, como o Staphylococcus $s p$, dentro dos fagócitos. Portanto, a eficácia do tratamento contra o Staphylococcus aureus é melhor durante o período seco.

No Brasil, o uso indiscriminado de medicamentos sem a realização de testes preliminares de sensibilidade "in vitro" e o uso de subdosagens, podem ocasionar agravamento do processo inflamatório, perdas econômicas, desenvolvimento de resistência microbiana e presença de resíduos de antimicrobianos (COSTA, 1996).

A implementação do tratamento intramamário, na secagem do animal, visa reduzir tanto o número de infecções pré-existentes quanto o número de novas infecções durante o período seco. Mais de $90 \%$ das infecções por Streptococcus agalactiae e 70\% das infecções por Staphylococcus aureus são eliminadas pelo tratamento de vaca seca (NAZTKE, 1972). Os autores relataram que usando "teat dipping" e tratamento de vaca seca, por três anos, o nível de mastite foi reduzido de $30 \%$ para $7 \%$. Segundo BARRAGRY (1994), a terapia da vaca seca controla $50 \%$ a $60 \%$ das infecções existentes.

Alguns autores preconizam que a aplicação de antibióticos no período seco seja realizada somente em vacas consideradas de risco ou as 
mais freqüentemente acometidas por mastite clínica (BROWNING et al., 1994; OSTERAS et al., 1994). Por outro lado, CAGIENARD (1983) concluiu que a terapia da vaca seca alcança melhores resultados em propriedades com altos índices de mastite clínica, em comparação com propriedades com baixa incidência.

\subsection{Período Seco e Lactação Subseqüente}

A glândula mamária requer um período não lactante, antes do parto, para otimizar a produção de leite na próxima lactação (HURLEY, 2002). O período seco corresponde a um estágio de involução da glândula mamária extremamente importante. Um intervalo, inferior a 60 dias, entre duas lactações, determina redução na produção leiteira na lactação subseqüente (SMITH et al., 1985; OLIVER \& SORDILLO, 1988).

A fisiologia da glândula mamária, durante o período seco, difere significativamente da fisiologia da mesma, durante a lactação. O período seco pode ser dividido em: involução ativa, repouso e colostrogênese.

Na vaca, a involução ativa está completa geralmente 21 dias após a secagem. Corresponde à fase de transição entre o período de lactação e o período seco. Nesses primeiros 21 dias há um aumento significativo na suscetibilidade às infecções intramamárias. O período de repouso varia muito, dependendo do número de dias de período seco. Infecções intramamárias, durante essa fase, não ocorrem com freqüência, pois existe uma grande resistência da glândula; quando elas ocorrem geralmente são de cura espontânea. A fase seguinte, a colostrogênese, marca a transição do período seco para o período lactacional e começa, geralmente, 30 dias antes do parto. Nesta fase, a suscetibilidade à mastite aumenta novamente, porque a glândula mamária começa a sofrer mudanças em decorrência da próxima lactação (HURLEY, 2002). 
COSTA et al., (1993) constataram que o final da lactação e o início do período seco são altamente dinâmicos, durante os quais o tecido passa de um estado de síntese ativa dos componentes lácteos à involução dos tecidos secretores e posteriormente à colostrogênese. Este período está também associado a uma brusca diminuição da retirada do leite da glândula, com conseqüente repleção das cisternas, ductos e alvéolos, além de serem registradas importantes mudanças na composição dos produtos secretórios. No final do período seco, a glândula se prepara para a síntese ativa e novamente ocorrem mudanças em sua histologia e morfologia.

Estudos demonstraram que a glândula mamária é altamente suscetível a novas infecções durante as transições da lactação para a involução e desta, para a colostrogênese (DUTT, 1986; NICKERSON, 1989; OLIVER \& SORDILLO, 1988). Esta afirmação pode ser explicada pela relação citrato: lactoferrina que, durante a colostrogênese, está elevada, havendo uma maior quantidade de citrato que serve de substrato para o crescimento bacteriano; além disso, a capacidade fagocitária está deprimida devido à grande quantidade de gordura que inibe a ação dos leucócitos.

Segundo NICKERSON (1990), o nível de novas infecções durante o processo de involução é seis vezes maior do que durante a lactação. Evidências clínicas e experimentais sugerem que estas mudanças, que ocorrem durante o período seco, fazem com que o úbere se torne mais susceptível às novas infecções (SMITH et al., 1985; OLIVER et al., 1984; COSTA et al., 1999; OLIVER \& SORDILLO, 1988). As infecções estabelecidas durante o período seco são as principais causadoras de mastite clínica nas primeiras semanas da próxima lactação, segundo RADOSTITIS (1994), OLIVER \& SORDILLO (1988) e EBERHART (1986).

Segundo OLIVER \& SORDILLO (1988), as infecções intramamárias ocorrem quando os microrganismos entram na glândula mamária via canal do teto e colonizam o sistema de ductos e os alvéolos, causando uma resposta inflamatória. Estes mesmos autores sugerem que a 
colostrogênese pode estar relacionada com a facilidade com que os microrganismos penetram na glândula mamária. O temporário aumento da pressão intramamária, seguido pela interrupção da lactação e acúmulo de colostro antes do parto, podem causar encurtamento e dilatação do canal do teto. Tal dilatação facilitaria a mobilidade das bactérias através do canal do teto até a cisterna do teto.

\subsection{Tratamento intramamário na interrupção da lactação}

A terapia da vaca seca foi utilizada pela primeira vez por PEARSON (1951) como um método de controle de mastite ambiental. Desde então, a terapia da vaca seca tem sido utilizada para eliminar as infecções já existentes e prevenir as novas infecções (HASSAN et al., 1999; BERRY \& HILLERTON, 2002).

A terapia da vaca seca é preconizada por vários autores, como PARKINSON et al., (2000), que verificaram uma eficiência de 100\% na prevenção das infecções durante o período seco ao utilizarem três diferentes tipos de antibióticos administrados em 493 vacas.

O tratamento da mastite tem sido tradicionalmente administrado por via intramamária, numa tentativa de concentração do agente quimioterápico no local ativo da infecção. Os produtos utilizados para vacas lactantes, são geralmente projetados para rápida eliminação dos resíduos no leite, diminuindo o tempo de descarte do mesmo e para a redução das restrições de suspensão do consumo do leite. Já as formulações para vacas secas, usando doses mais elevadas de antibióticos em meios mais oleosos ou em veículos de depósito, são projetados para a produção de intervalos prolongados de concentrações antibióticas efetivas (SMITH, 1994),

Vários trabalhos sobre a eficácia da terapia de vaca seca têm sido publicados. Algumas vantagens desta terapia são: a possibilidade de 
utilização de preparações de longa persistência, o fato de não envolver o descarte do leite, o uso de dose única e uma melhor resposta da glândula em repouso ao tratamento. Este tipo de procedimento, além de auxiliar na redução das infecções pré-existentes, tem a finalidade de prevenir novas infecções no período seco (WATANABE, 1999).

Em trabalho realizado por HASSAN et al., (1999), a terapia da vaca seca resultou em uma significativa redução no número de quartos infectados nas primeiras quatro semanas após a secagem, quando comparada com os grupos de animais que não foram tratados no momento da secagem. Casos de mastite clínica foram detectados, duas semanas depois da secagem, nos animais que não receberam tratamento.

Apesar do tratamento de vaca seca ser eficiente em mais de $90 \%$ das infecções causadas por Streptococcus agalactiae e prevenir novas infecções causadas por este mesmo microrganismo, a terapia não consegue ultrapassar $70 \%$ de eficácia nas infecções causadas por Staphylococcus aureus. Muitas infecções por Staphylococcus aureus persistem, resultando em casos de mastite clínica na lactação subseqüente (NICKERSON et al., 1999).

\subsection{Limite máximo de resíduos de antimicrobianos}

Segundo o CODEX ALIMENTARIUS FAO/OMS (1997), resíduo de uma droga veterinária é fração da droga, seus metabólitos, produtos de conversão ou reação e impurezas que permanecem no alimento originário de animais tratados.

O limite máximo de resíduo (LMR) recomendado pelo CODEX ALIMENTARIUS, é definido como a concentração máxima da droga (expressa em $\mathrm{mg} / \mathrm{Kg}$ ou $\mu \mathrm{g} / \mathrm{Kg}$ ), legalmente permitida ou reconhecida como aceitável no alimento. Baseia-se no tipo e quantidade do resíduo, considerando o perigo toxicológico para a saúde humana, com base na dose 
diária aceitável (IDA) ou na IDA temporária, que utiliza um fator de segurança adicional (BRITO, 2003).

A IDA é a quantidade de um agente químico presente no alimento que pode ser ingerido através da dieta, diariamente, durante toda a vida do indivíduo, sem provocar risco de intoxicação para os seres humanos. Também é determinado o intervalo de tempo que deve decorrer para que os resíduos diminuam, atingindo os níveis de tolerância. Este intervalo é denominado período de carência (NOUWS et al., 1994; MIDIO \& MARTINS, 2000).

O período de carência é alcançado através de análises farmacocinéticas específicas para cada medicamento (MITCHELL et al., 1998). Fica sob responsabilidade da indústria produtora dos antimicrobianos, o desenvolvimento de métodos analíticos que permitam a detecção e quantificação dos resíduos e cabe ao FDA aprová-los ou não (KISER, 1984).

Segundo a Instrução Normativa $n^{0} 51$ de 2002, que trata sobre a legislação atual do leite e seus derivados, o controle e monitoramento rotineiro de resíduos de antimicrobianos é de responsabilidade dos pequenos laticínios ou da indústria captadora. Uma vez por mês, o responsável pelos produtos oferecidos ao consumidor deve enviar amostras de leite a um laboratório da rede credenciada ao Ministério da Agricultura para análise de monitoramento oficial.

Na prática, tem-se observado que a indústria vem fazendo este monitoramento, uma vez que, os resíduos afetam diretamente a fabricação de produtos lácteos fermentados e a saúde do consumidor. Algumas indústrias têm utilizado este critério para penalizar produtores que enviam leite com resíduos de antimicrobianos (http://www.milkpoint.com.br, disponível em 14 de junho de 2001). 
Na Tabela 1 são apresentados os LMR de alguns antimicrobianos, de acordo com a regulamentação da FAO/ OMS, União Européia, FDA e o Ministério da Agricultura, Pecuária e Abastecimento (MAPA). Alguns desses valores estão estabelecidos enquanto outros são preliminares e sujeitos a revisão (desde que novas informações sobre as substâncias se tornem disponíveis). 
Tabela 1- Limite Máximo permitido de resíduos de antimicrobianos no leite $(\mathrm{mg} / \mathrm{Kg})$, de acordo com a Comissão do Codex Alimentarius (CODEX), Food and Drug Administration (EUA), União Européia e Ministério da Agricultura, Pecuária e Abastecimento (MAPA).

\begin{tabular}{|c|c|c|c|c|}
\hline Substância & $\begin{array}{c}\text { Codex } \\
\text { LMR } \\
(\mu \mathrm{g} / \mathrm{Kg})\end{array}$ & $\begin{array}{c}\text { EUA/FDA } \\
\text { Tolerância } \\
(\mu \mathrm{g} / \mathrm{Kg})\end{array}$ & $\begin{array}{c}\text { EU LMR } \\
(\mu \mathrm{g} / \mathrm{Kg})\end{array}$ & $\begin{array}{c}\text { Brasil }^{1} \\
\text { LMR } \\
(\mu \mathrm{g} / \mathrm{Kg})\end{array}$ \\
\hline Penicilina G & 4 & 5 & 4 & 4 \\
\hline Ampicilina & - & 10 & 4 & 4 \\
\hline Amoxicilina & - & 10 & 4 & 4 \\
\hline Oxacilina & - & - & 30 & - \\
\hline Cloxacilina & - & 10 & 30 & - \\
\hline Dicloxacilina & - & - & 30 & - \\
\hline Penetamato & - & - & 4 & - \\
\hline Ceftiofur & 100 & 50 & 100 & 100 \\
\hline Cefquinone & - & - & 20 & - \\
\hline Cefapirina & - & 20 & - & - \\
\hline Etraciclina & 100 & 80 & 100 & 100 \\
\hline Clortetraciclina & 100 & 30 & 100 & 100 \\
\hline Oxitetraciclina & 100 & 30 & 100 & 100 \\
\hline Espiramicina & - & - & 200 & 200 \\
\hline Tylosina & - & 50 & 50 & - \\
\hline Eritromicina & - & 50 & 40 & 40 \\
\hline Espectinomicina & 200 & 30 & 200 & - \\
\hline DH/Estreptomicina & 200 & 150 & 200 & - \\
\hline Gentamicina & 200 & 30 & 100 & - \\
\hline Neomicina & 500 & 150 & 500 & 500 \\
\hline Sulfonamidas & - & - & 100 & - \\
\hline Sulfadimidina & 25 & 10 & - & - \\
\hline
\end{tabular}


Tabela 1 - Limite Máximo permitido de resíduos de antimicrobianos no leite $(\mathrm{mg} / \mathrm{Kg})$, de acordo com a Comissão do Codex Alimentarius (CODEX), Food and Drug Administration (EUA), União Européia e Ministério da Agricultura, Pecuária e Abastecimento (MAPA). (Conclusão)

\begin{tabular}{ccccc}
\hline Substância & $\begin{array}{c}\text { Codex } \\
\text { LMR } \\
(\mu \mathrm{g} / \mathrm{Kg})\end{array}$ & $\begin{array}{c}\text { EUA/FDA } \\
\text { Tolerância } \\
(\mu \mathrm{g} / \mathrm{Kg})\end{array}$ & $\begin{array}{c}\text { EU LMR } \\
(\mu \mathrm{g} / \mathrm{Kg})\end{array}$ & $\begin{array}{c}\text { Brasil } \\
\text { LMR } \\
(\mu \mathrm{g} / \mathrm{Kg})\end{array}$ \\
\hline $\begin{array}{c}\text { Sulfadimetoxina } \\
\text { Sulfamerazina }\end{array}$ & - & 10 & - & 100 \\
Sulfatiazol & - & 10 & - & - \\
Sulfadiazina & - & 10 & - & 100 \\
Trimetoprim & - & 10 & - & - \\
Furazolidona & - & - & 50 & - \\
Ronidazol & - & - & - & - \\
Dimetridazol & - & - & - & - \\
Cloranfenicol & 0 & - & - & - \\
Novobiocina & - & 0 & 0 & - \\
\hline
\end{tabular}

${ }^{1}$ Programa de Controle de Resíduos em Leite; PCRL/ 2000, Instrução Normativa no 42, de 20/12/1999.

Fonte: BRITO, 2003.

\subsection{Resíduos de antimicrobianos e a mastite}

O leite dos animais com mastite difere, em composição e propriedades, do leite de animais sadios, podendo afetar a eliminação de antibióticos (MORETAIN e BOISSEAU, 1993; COSTA, 1999). O tempo de eliminação do antibiótico em quartos com mastite pode ser maior do que em quartos saudáveis (MOL, 1975; RAIA et al., 1999).

RAIA (2001) verificou que há influência do processo inflamatório no período de eliminação do antimicrobiano no leite. Observou, no mesmo estudo, que havia alta correlação $(r=1)$ entre o nível de ocorrência de mastite clínica e a presença de resíduo no leite armazenado em tanques resfriadores de propriedades leiteiras nos Estados de São Paulo e Minas Gerais. Como conclusão geral, o autor referiu que somente a informação do 
fabricante do medicamento quanto ao período de carência, algumas vezes, não é suficiente para garantir um leite livre de resíduo, sendo, portanto, importante à orientação aos produtores e veterinários sobre os procedimentos para evitar resíduos de antimicrobianos no leite.

Em relação ao tratamento intramamário, principal fonte de resíduo no leite (CULLOR, 1993; GARDNER et al., 1996), é comum observar a prática de descarte do leite somente das glândulas tratadas, por serem independentes entre si (JONES \& SEYMOUR, 1988). No entanto, através da circulação sanguínea e da difusão entre as glândulas, já foi verificada a presença de resíduo também nos quartos não tratados de animais tratados por via intramamária (HAWKINS et al., 1962; ZIV et al., 1974; EGAN \& MEANEY, 1985; COSTA et al., 2000).

Os principais fatores que podem afetar a taxa de excreção e a presença de antibióticos no leite são: a quantidade de leite produzida pelo animal e o intervalo de tempo entre o tratamento e a ordenha (MARTH \& ELLICKSON, 1959), os tipos de antibióticos e veículos utilizados, as vias de administração e as doses administradas (CANNON et al., 1972, COSTA et al., 1999).

Apesar da relevância do assunto há escassez de estudos sobre a ocorrência de resíduos no leite após o período seco. Há necessidade dos animais serem avaliados, para assegurar que, após este período, o leite destes se apresente isento de resíduos de antimicrobianos e possa ser liberado para consumo.

O assunto foi avaliado por alguns autores nas décadas de 70 e início de 80 (JOHNSON et al., 1977; OLIVER et al., 1984), mas, com a evolução técnica, têm sido utilizados excipientes que propiciam maior persistência dos antibióticos na glândula mamária, o que pode determinar maior risco de ocorrência de resíduos. 
A presença de resíduos de antibióticos no leite decorre, principalmente, do abuso destes medicamentos ou da sua utilização de maneira inadequada, como, por exemplo, uso de medicamentos não recomendados e com farmacocinética não perfeitamente estabelecida; uso de doses excessivas e não obediência ao período de descarte do leite de animais em tratamento, além de problemas idiossincrásicos de animais que apresentam uma prolongada retenção do medicamento (COSTA, 1999).

Ao se abordar a questão da presença de resíduos no leite, é importante que se diferencie corretamente os termos "antibióticos" e "resíduos de antibióticos". SPINOSA et al. (1999) definiram antibióticos, sob o aspecto farmacológico, como substâncias químicas (medicamentos) produzidas por alguns microrganismos ou seus equivalentes sintéticos capazes de, em pequenas doses, inibir o crescimento (bacteriostásticos, fungistáticos etc.) ou destruir (bactericidas, fungicidas) microrganismos causadores de doenças. ALVIM \& BRANDÃO (2001) propuseram definir antibióticos como inibidores específicos de sistemas enzimáticos de estruturas celulares vitais para a sobrevivência de microrganismos, enquanto "resíduos de antibióticos" como compostos bioativos que restam nos animais devido ao seu uso terapêutico, podendo causar ações biológicas nos seres humanos consumidores de produtos de origem animal.

A quantidade de resíduo de antibiótico excretada no leite varia entre os diferentes indivíduos, consoante à quantidade de leite que a vaca produz e o excipiente de preparação utilizado. A administração de doses elevadas e a produção de quantidades escassas de leite determinam largas permanências de antibióticos no úbere (FAGUNDES et al., 2000).

BARROS e PERCHES (1981) analisando 96 amostras de leites pasteurizados do tipo B, comercializado na cidade de São Paulo, encontraram 21,9\% das amostras com presença de resíduos de antibióticos. GELLI et al., (1984), analisando 404 amostras de leite pasteurizado na cidade de São Paulo, SP, verificaram que $11,63 \%$ foram positivas para a 
presença de antibióticos. ALBUQUERQUE et al., (1996) observaram que de um total de 300 amostras de leite comercializado em Fortaleza, Ceará, $69,7 \%$ foram positivas para a presença de resíduos. LOPES et al., (1998) avaliaram 178 amostras de leite comercializado em Campinas, São Paulo, encontrando $7,9 \%$ das amostras positivas para resíduo.

\subsection{Presença de resíduos de antimicrobianos no leite e os riscos à saúde pública}

A presença de resíduo de antimicrobianos no leite é indesejável por várias razões, sendo as mais freqüentes as reações de hipersensibilidade e seleção de microrganismos patogênicos resistentes (COSTA, 1999). Segundo LEME et al., (1999), o principal problema não é o resíduo de agente antimicrobiano per se utilizado na produção animal, mas os patógenos resistentes que podem ser selecionados pelo uso de doses sub-terapêuticas de antibióticos, permanecendo na microbiota intestinal ou no ambiente e transmitidos para os humanos via alimento.

Embora os níveis aceitáveis de resíduos de antimicrobianos no leite sejam inferiores ao limite mínimo necessário para produzir reações alérgicas agudas, não se sabe se a exposição freqüente à baixas concentrações de tais medicamentos possa causar efeitos nocivos ao consumidor. A maioria das informações relativas à hipersensibilidade está associada ao uso da penicilina, além de relatos de que aminoglicosídeos, cloranfenicol e novobiocina sejam, também, fortemente alergênicos em indivíduos sensíveis (DENOBILE, 2002).

As reações alérgicas estão, freqüentemente, associadas $\beta$ lactâmicos, particularmente à penicilina, mas podem ser observadas também quando do uso de outros antibióticos. Alergias aos aminoglicosídeos são raras, mas, às vezes, ocorrem erupções cutâneas urticariformes após o uso desta e de outras classes de antibióticos (COSTA et al., 1999). Além das 
reações alérgicas, outros problemas podem ocorrer associados ao uso de cloranfenicol como, por exemplo, discrasia sangüínea, anemia aplástica e neurite ótica (SUNDLOF, 1989).

Segundo STOBBERINGH e BOGAARD (2000), o uso de antibióticos em animais, bem como em seres humanos, não causaria somente o aumento da seleção de bactérias patogênicas resistentes, mas, também, a resistência das bactérias normais da microbiota intestinal, que poderiam infectar a população humana tanto por contato direto como através da ingestão de produtos de origem animal, como o leite.

Há alguns anos, pesquisadores vêm mostrando interesse no estudo dos possíveis efeitos de resíduos de drogas microbiologicamente ativas sobre a microflora intestinal humana. Os efeitos adversos dos antimicrobianos sobre a microbiota intestinal são preocupantes devido ao importante papel que desempenham na manutenção da saúde dos indivíduos. Além disso, perturbações na microbiota intestinal podem comprometer a eficácia de outras substâncias terapêuticas e, deste modo, afetar negativamente a saúde pública (PAIGE, 1998).

Em virtude da preocupação em associar resistência bacteriana e saúde infantil, a atenção com a qualidade química de alimentos para bebês e crianças é fundamental, não devendo ocorrer acúmulo ou concentração indesejável (ALVIM \& BRANDÃO, 2001). Além disso, a preocupação com as gestantes deve ser considerada, pois, não apenas os nutrientes consumidos por elas, mas, também, resíduos e contaminantes presentes nos alimentos ingeridos podem ser passados para o bebê via amamentação, podendo causar efeitos teratogênicos. Em estudo com mulheres lactantes observaram a ocorrência de diarréia em crianças alimentadas com leite materno de mães que haviam recebido antibioticoterapia durante esta fase; mesmo em doses terapêuticas, as diarréias neonatais atribuídas a antibioticoterapia materna foram da ordem de 13\%. (TADDIO, 1994). 
O principal risco à saúde pública são as reações alérgicas (risco imunopatológico) que podem desencadear choque anafilático em indivíduos particularmente sensíveis (AURVALLE, 1981; FAGUNDES \& MOLIN, 1988; MARTH \& ELLICKSON, 1959). GERALD (1981) alerta para o fato de que cerca de 5 a 10\% da população possui sensibilidade a algum tipo de antibiótico. Doses a partir de 0,03 UI/ml de penicilina são suficientes para causar reações em pessoas sensíveis (MELLO, 1969).

\subsection{Testes de detecção de resíduos de antimicrobianos no leite}

A importância da presença de resíduos de antimicrobianos no leite incentivou o desenvolvimento de vários testes para detecção destes resíduos (BARBERIO e SIGNORINI, 1996). Estas técnicas encontram-se disponíveis no mercado sob a forma de conjuntos de reativos prontos para uso em condição de campo. Os conjuntos foram inicialmente desenvolvidos para utilização em plataformas de recebimento de leite nas usinas, porém, têm sido aplicados, também, em propriedades rurais, para verificar a presença de resíduos no leite armazenado nos tanques ou proveniente de vacas mantidas sob tratamento com antibióticos (ANDREW et al., 1997).

Para garantir amostras livres de resíduos de drogas, muitos métodos têm sido usados: como o método de inibição microbiológica, métodos imunológicos, métodos enzimáticos, cromatografia gasosa, cromatografia em camada delgada e cromatografia líquida de alta pressão (KANG \& KONDO, 2001).

Atualmente, existem vários testes disponíveis comercialmente para detecção de resíduos de antibióticos em leite (Tabela 2). Na triagem de resíduos de antibióticos em leite são mais comumente utilizados os testes de inibição microbiana e os testes rápidos específicos para substâncias ou grupos de substâncias (REYBROECK, 1995a). O método de inibição 
microbiana pela presença de resíduos de antimicrobianos no leite é o mais utilizado em virtude do custo e da capacidade de evidenciar uma ampla gama de antibióticos e quimioterápicos (BARBERIO e SIGNORINI, 1996). $\mathrm{Na}$ Tabela 3 estão apresentados os limites de sensibilidade de dois microrganismos empregados em testes microbiológicos de detecção de resíduos no leite. 
Tabela 2 - Kits para detecção de resíduos de antibióticos no leite disponíveis no mercado.

\begin{tabular}{|c|c|}
\hline Princípio do teste & Teste \\
\hline \multirow{8}{*}{ Inibição do Crescimento Bacteriano } & Teste do Disco \\
\hline & BR - Test \\
\hline & BR - Test " Blue Star" \\
\hline & BR - Test AS \\
\hline & Charm Farm Test \\
\hline & Charm Inhibition assay \\
\hline & Delvotest P \\
\hline & Delvotest SP \\
\hline \multirow{3}{*}{ Receptor } & Charm cowside Test \\
\hline & Charm I test \\
\hline & Charm II test \\
\hline Ligação à proteína & CITE Probe ( $\beta$ - lactâmicos) \\
\hline \multirow{4}{*}{ ELISA } & $\begin{array}{l}\text { CITE Probe (tetraciclina, } \\
\text { gentamicina) }\end{array}$ \\
\hline & CITE sulfa trio \\
\hline & EZ - screen \\
\hline & $\begin{array}{c}\text { Lac tek ( } \beta \text { - lactâmicos, gentamicina, } \\
\text { sulfametazina })\end{array}$ \\
\hline \multirow{2}{*}{ Enzima } & Penzyme \\
\hline & IDEXX SNAP test \\
\hline Aglutinação em látex & SPOT test \\
\hline
\end{tabular}

Fonte: Cullor, 1992. 
Tabela 3 - Limites de sensibilidade (em $\mu \mathrm{g} / \mathrm{Kg}$ ) de diferentes testes de inibição do crescimento microbiano para diferentes antimicrobianos.

\begin{tabular}{|c|c|c|c|}
\hline \multirow[t]{2}{*}{ Antimicrobianos } & $\begin{array}{c}\text { Bacillus } \\
\text { stearothermophilus } \\
\text { var. calidolactis }\end{array}$ & & $\begin{array}{c}\text { Streptococcus } \\
\text { salivarius } \\
\text { subsp } \\
\text { thermophilus }\end{array}$ \\
\hline & $\begin{array}{c}\text { Método de difusão } \\
\text { em tubo }\end{array}$ & Delvotest $^{\circledR}$ SP & Valiotest T101 \\
\hline Benzilpenicilina & 3 & 3 & 5 \\
\hline Ampicilina & 6 & 6 & 25 \\
\hline Amoxicilina & 6 & 6 & 40 \\
\hline Cloxacilina & 25 & 25 & 200 \\
\hline Ceftiofur & 40 & 50 & 20 \\
\hline Oxitetraciclina & 750 & 1000 & 400 \\
\hline Tylosina & 20 & 50 & 20 \\
\hline Eritromicina & 10 & 200 & 75 \\
\hline Espectinomicina & 750 & 3000 & 1500 \\
\hline Dihidroestreptomicina & 250 & 1500 & 400 \\
\hline Gentamicina & 50 & 200 & 1500 \\
\hline Sulfadimidina & 500 & 150 & $>5000$ \\
\hline Dapsona & 2 & 2 & $>2000$ \\
\hline Cloranfenicol & 5000 & 7500 & 1500 \\
\hline
\end{tabular}

Fonte: Honkanen- Buzalski \& Reybroeck (1997).

A partir da década de 50, o método de ensaio de disco com Bacillus subtilis e suas modificações foram usados para detectar resíduos de antimicrobianos no leite. Durante os anos 70 e 80 ocorreu o desenvolvimento de técnicas radioimunológicas e enzimáticas para determinar a presença de $\beta$-lactâmicos e outros antimicrobianos, tais como: tetraciclinas, estreptomicinas, eritromicina, novobiocina, e sulfonamidas. 
Outros testes determinam a presença de resíduos de $\beta$-lactâmicos baseados na inibição da reação de enzimas específicas. Finalmente, durante os anos 80 foram introduzidos testes utilizando anticorpos para resíduos específicos (BISHOP et al., 1992).

Diversos trabalhos indicam que os produtores de leite que utilizam testes seletivos para avaliação de antibióticos no leite possuem menor incidência de resíduos em seus produtos. Deve-se ressaltar, contudo, que o desempenho dos conjuntos pode variar amplamente quando utilizado no leite de diferentes animais, afetando, principalmente, a capacidade do teste em detectar resíduos em amostras comprovadamente positivas. Com relação aos antibióticos $\beta$-lactâmicos, alguns trabalhos demonstram que a especificidade é menor quando realizado no leite de animais acometidos de mastite clínica (CORASSIN \& OLIVEIRA, 2000).

Outro método bastante utilizado para a detecção de resíduos de antimicrobianos no leite é o imunoenzimático, conhecido como Elisa (Enzyme linked immunoadsorbant assay). Entre as vantagens desta técnica, destacam-se a rapidez e a simplicidade de execução, maior especificidade para determinados antibióticos e possibilidade de detecção de outros agentes antimicrobianos, além de antibióticos.

De acordo com a Portaria $\mathrm{n}^{\circ}$ oito de 26/06/84 do Serviço de Inspeção Federal do Ministério da Agricultura, publicada no Diário Oficial da União em 11/07/84 (BRASIL, 1984), pelo menos uma vez por semana devem ser realizadas, obrigatoriamente, pesquisas de inibidores em amostras de leite de pequena mistura pelo método TTC (cloreto 2-3-5-trifenil tetrazólio), método de disco em placas, Delvotest ${ }^{\circledR} \mathrm{SP}$, ou outro aprovado.

Quanto aos testes comercialmente disponíveis para aplicação à campo, estes são, na sua maioria, qualitativos ou semi-quantitativos, sendo conhecidos como testes de triagem. Existe entre eles, uma variação quanto à classe de antimicrobianos detectável, sensibilidade e tempo de realização 
(MITCHELL et al., 1998). De acordo com o protocolo desenvolvido para avaliação dos testes, o padrão de seletividade requer que o teste identifique corretamente, com 95\% de confiança, leite que não contenha resíduos em 90\% das amostras (90/95). O padrão de sensibilidade inicial seria, então, detectar leite com resíduos de antibióticos no limite de tolerância/segurança (LMR) em 90\% das vezes, com 95\% de confiança (BRITO, 2003).

Os testes de triagem mais utilizados são os de inibição do crescimento microbiano e testes rápidos específicos para determinados grupos de substâncias (REYBROECK, 1995a). Embora vários autores tenham relatado enfaticamente a ocorrência de resultados falso-positivos, o Delvotest ${ }^{\circledR}$ SP é amplamente utilizado individualmente em vacas e seu uso está, inclusive, recomendado no programa de segurança da qualidade do leite e da carne existente nos EUA (CULLOR et al., 1994).

O Delvotest ${ }^{\circledR} \mathrm{SP}$, é um teste rápido de inibição do crescimento e da produção de ácido pelo microrganismo Bacillus stearothermophilos variedade calidolactis. Na presença de resíduo de drogas, a cor púrpura original do indicador de $\mathrm{pH}$ não se altera. É um teste simples, sensível e relativamente rápido, quando comparado a outros. Seu uso está aprovado pelo FDA e é reconhecido e aprovado pela Association of Official Analytical Chemist (AOAC) desde 1982.

Os métodos que empregam princípios microbiológicos, como é o caso do Delvotest ${ }^{\circledR} \mathrm{SP}$, contudo, apresentam certas desvantagens, pois necessitam de equipamentos e conhecimento técnico especializado para sua execução; além disso, os resultados não são imediatos, somente drogas antibacterianas são detectáveis e a interferência de outras substâncias pode provocar resultados falso-positivos (ANDREW et al., 1997).

O FDA estabeleceu conceitos importantes no entendimento e avaliação do uso de testes para detecção de resíduos (FOOD \& DRUG ADMINISTRATION, 1999; CULLOR et al., 1994), definindo como resultado 
verdadeiramente positivo aquele onde a amostra possui concentração de droga igual ou maior ao nível de tolerância ou segurança estabelecido.

Existem diversas vantagens em analisar individualmente o leite de vacas que foram tratadas com antibióticos, porém, as principais estão relacionadas aos aspectos econômicos e de qualidade do leite produzido (CORASSIN \& OLIVEIRA, 2000). A abordagem tradicional de controle de resíduos de antibióticos no leite preconiza a análise de amostras colhidas nas plataformas das usinas ou no tanque de armazenagem de leite nas propriedades rurais.

O primeiro aspecto benéfico na análise individual dos animais está relacionado ao fato de que, se a análise do tanque for positiva para resíduos, o impacto financeiro será muito maior que o decorrente de um resultado positivo para uma vaca. A qualidade do leite produzido, por outro lado, também é assegurada, pois o teste individual das vacas previne a contaminação de todo o produto ordenhado e recolhido no tanque. É importante lembrar que a adição de leite contendo antibióticos, ao leite não contaminado, nem sempre consegue diluir os resíduos no leite de mistura até os níveis de tolerância (CORASSIN \& OLIVEIRA, 2000).

Quanto à influência do processo inflamatório sobre a positividade do teste, RAIA (2001), analisando, 46 amostras de quartos não tratados individualmente, observou $33 \%$ de resultados falso positivos para os quartos com mastite clínica e $18 \%$ para os casos de mastite subclínica, utilizando o teste de inibição bacteriana, Delvotest ${ }^{\circledR} \mathrm{SP}$. No mesmo estudo, o autor, seguindo as orientações de AERTS et al., (1995), demonstrou que o aquecimento prévio das amostras a $80^{\circ} \mathrm{C}$, durante cinco minutos, eliminava todas as reações falso-positivas.

KANG \& KONDO (2001), avaliaram 321 quartos individuais sem alterações visuais observada pelo teste da caneca preta, quanto à ocorrência de resultados falso positivos ao Delvotest ${ }^{\circledR} \mathrm{SP}$. As taxas 
observadas no estudo foram de 4,04\%, para amostras de quartos individuais; 4,3\%, para amostras compostas e 1,3\%, para amostras de tanque. Os autores observaram, ainda, diferenças nos resultados quanto ao momento de leitura. Leituras às 2:50 horas, após a incubação, apresentaram menores taxas de falso positivos. Assim, este tem sido o intervalo de tempo recomendado para a leitura. 


\section{MATERIAL E MÉTODOS}

\subsection{Material}

\subsubsection{Delineamento Experimental}

Durante o período de Fevereiro a Julho de 2002, 74 animais da raça holandesa preto e branca, pertencentes a três propriedades leiteiras, do estado de São Paulo, foram examinados para a avaliação da presença de resíduos de antimicrobianos em glândulas mamárias tratadas na interrupção da lactação (Tratamento de Vaca Seca). Os animais foram distribuídos aleatoriamente em três grupos (tratamento), e tratados por via intramamária com produtos comerciais diferentes:

$\checkmark$ Tratamento 1 (Cefalônio anidro ${ }^{1}$ 0,25 g): Constituído de 17 animais num total de 68 glândulas.

$\checkmark$ Tratamento 2 (100 mg de hidroiodeto de penetamato $105.800 \mathrm{UI}+280 \mathrm{mg}$ de penicilina benetamina $304.920 \mathrm{UI}+100 \mathrm{mg}$ de sulfato de framicetina ${ }^{2}$ ): Constituído de 31 animais num total de 122 glândulas.

$\checkmark$ Tratamento 3 (Benzilpenicilina procaína 297,92 mg - $300.000 \mathrm{UI}+$ monoidrato sódico de nafcilina 121,95 mg equivalente a $100 \mathrm{mg}$ de nafcilina + sulfato de diidroestreptomicina $34,23 \mathrm{mg}$ equivalente a $100 \mathrm{mg}$ de diidroestreptomicina ${ }^{3}$ ): Constituído de 26 animais num total de 99 glândulas.

\footnotetext{
${ }^{1}$ Cepravin VS Coopers

${ }^{2}$ Mamizin Vaca Seca ${ }^{\circledR}$, Boehringer Ingelhein

${ }^{3}$ Nafpenzal ${ }^{\circledR}$ S, Intervet
} 


\subsubsection{Caracterização das propriedades leiteiras}

As propriedades leiteiras, representadas pelas letras PA, PB e PC, estão localizadas em diferentes municípios do estado de São Paulo, e, as principais características de manejo, higiene de ordenha, medidas de prevenção de mastite, rotina de tratamentos e medicamentos rotineiramente utilizados, estão dispostas nas Tabelas 4, 5 e 6 respectivamente.

Tabela 4 - Características das propriedades leiteiras. Pirassununga, São Paulo. 2003

\begin{tabular}{|c|c|c|c|}
\hline $\begin{array}{l}\text { Propriedades } \\
\text { Leiteiras }(P)^{4}\end{array}$ & PA & PB & PC \\
\hline Tipo de Leite & $A$ & B & $A$ \\
\hline Raça & HPB & HPB & HPB \\
\hline $\begin{array}{c}\text { Rebanho em } \\
\text { lactação animais }\end{array}$ & 900 & 240 & 94 \\
\hline Produção & $\begin{array}{c}27.000 \\
\text { Kg/leite/dia }\end{array}$ & $2.600 \mathrm{Kg} / \mathrm{leite} / \mathrm{dia}$ & $2.500 \mathrm{Kg} /$ leite/dia \\
\hline Ordenha / tipo & $\begin{array}{c}\text { Mecânica/lado a } \\
\text { lado }\end{array}$ & $\begin{array}{c}\text { Mecânica/espinha } \\
\text { de peixe }\end{array}$ & $\begin{array}{l}\text { Mecânica/espinha } \\
\text { de peixe }\end{array}$ \\
\hline No Ordenhas & Três ordenhas & Duas ordenhas & Duas ordenhas \\
\hline $\begin{array}{l}\text { Assistência } \\
\text { Veterinária }^{5}\end{array}$ & Permanente & $\begin{array}{l}\text { Só área } \\
\text { reprodutiva }\end{array}$ & Permanente \\
\hline $\begin{array}{l}\text { Higiene das } \\
\text { Instalações }\end{array}$ & Boa & Boa & Boa \\
\hline $\begin{array}{l}\text { Higiene do } \\
\text { equipamento de } \\
\text { ordenha }\end{array}$ & $\begin{array}{c}\text { Limpeza } \\
\text { automática }\end{array}$ & $\begin{array}{c}\text { Limpeza } \\
\text { automática }\end{array}$ & $\begin{array}{c}\text { Limpeza } \\
\text { automática }\end{array}$ \\
\hline $\begin{array}{l}\text { Resfriamento do } \\
\text { Leite }\end{array}$ & $\begin{array}{l}\text { Tanque de } \\
\text { resfriamento }\end{array}$ & $\begin{array}{l}\text { Tanque de } \\
\text { resfriamento }\end{array}$ & $\begin{array}{l}\text { Tanque de } \\
\text { resfriamento }\end{array}$ \\
\hline
\end{tabular}

\footnotetext{
${ }^{4}$ Descalvado, Pirassununga e São Miguel Arcanjo respectivamente, Estado de São Paulo.

${ }^{5}$ Assistência Veterinária - Permanente (Veterinário presente 24 horas na propriedade).

${ }^{6}$ Higiene das instalações - Satisfatória (Boa) (limpeza diária de todas as instalações).
} 
Tabela 5 - Características de manejo, higiene de ordenha e medidas de prevenção de mastite das propriedades. Estado de São Paulo. 2003

\begin{tabular}{cccc}
\hline $\begin{array}{c}\text { Higiene de } \\
\text { ordenha }\end{array}$ & PA & PB & PC \\
\hline Mão de Obra & Boa & Boa & Boa \\
Tamis & Sim & Sim & Sim \\
Pré-dipping & Cloro* & Sim & Não \\
Enxugar tetos & Papel toalha & Papel toalha & Papel toalha \\
Pós-dipping & Cloro* & lodo 0,7\% & lodo* \\
\hline
\end{tabular}

*Conforme indicação do fabricante

Tabela 6 - Rotina de Tratamentos de mastite: medicamentos habitualmente utilizados. Estado de São Paulo. 2003

\begin{tabular}{|c|c|c|c|}
\hline $\begin{array}{c}\text { Tratamentos de mastite } \\
\text { utilizados }\end{array}$ & PA & PB & PC \\
\hline $\begin{array}{c}\text { Tratamento de Mastite } \\
\text { Clinica }\end{array}$ & $\begin{array}{c}\text { Pathozone }^{\circledR}, \\
\text { Mastijet }^{\circledR} \\
\text { Mamyzin }^{\circledR}\end{array}$ & Mastifin $^{\circledR}$ & $\begin{array}{l}\text { Gentocin }^{\circledR} \\
\text { Bovigan }^{\circledR} \\
\text { Mamyzin }^{\circledR}\end{array}$ \\
\hline Tempo de Tratamento & Três dias & Três dias & $\begin{array}{l}\text { Conforme } \\
\text { indicação do } \\
\text { fabricante }\end{array}$ \\
\hline $\begin{array}{l}\text { Descarte do leite/ } \\
\text { período }\end{array}$ & Nove ordenhas & Não & $\mathrm{Sim}^{\star}$ \\
\hline Tipo de secagem & Abrupta & Abrupta & Abrupta \\
\hline $\begin{array}{c}\text { Tratamento secagem } \\
\text { medicamento }\end{array}$ & $\begin{array}{c}\text { Cepravin VS } \\
\text { Mamyzin }^{\circledR}\end{array}$ & Mastifin ${ }^{\circledR}$ & $\begin{array}{c}\text { Mastifin }^{\circledR} \\
\text { Mamyzin }^{\circledR}\end{array}$ \\
\hline
\end{tabular}

* Conforme indicação do fabricante

\footnotetext{
${ }^{7}$ Mão de Obra - Boa (qualificada para o trabalho de acordo com os padrões exigidos na propriedade).
} 


\subsection{Métodos}

$\checkmark$ A escolha dos medicamentos não foi baseada nos resultados de testes de sensibilidade in vitro (antibiogramas).

$\checkmark$ Todas as glândulas mamárias de uma mesma vaca receberam o mesmo tratamento.

$\checkmark$ Cada glândula consistiu uma unidade experimental.

$\checkmark$ Os animais que constituíram os grupos apresentaram período seco médio de 66 dias, onde o período mínimo foi de 44 dias e o máximo de 82 dias.

Todos os animais foram submetidos à secagem abrupta.

$\checkmark$ Foram realizadas duas avaliações: a primeira na interrupção da lactação, após a última esgota do animal e a outra entre os primeiros 10 dias pós-parto.

$\checkmark$ Animais com manifestação clínica de mastite durante o período seco, foram registrados e amostras da secreção foram colhidas para exame microbiológico e, quando necessário, instituía-se outro tratamento, sendo então os animais excluídos dos grupos experimentais.

Informações sobre idade dos animais, produção no dia da secagem, média de produção da lactação anterior, número de lactações e data provável do parto foram registradas para a avaliação e possíveis correlações na ocorrência de resíduo de antimicrobianos no leite. 


\subsubsection{Colheita das amostras}

No dia da secagem, após a última ordenha, os animais foram sorteados e alocados nos grupos de tratamento (1, 2 ou 3). Procedeu-se o teste da "caneca de fundo preto" em todos os animais para detecção de mastite clínica e para detecção de mastite subclínica realizou-se o CMT ("Califórnia Mastitis Test", de acordo com SCHALM \& NOORLANDER, 1957). Posteriormente, amostras de leite para exame microbiológico foram colhidas. Depois de colhido o material, a glândula mamária foi novamente esgotada (manualmente) para proceder à infusão intramamária do medicamento previamente selecionado.

Durante os primeiros dez dias após o parto, foram novamente realizadas as provas da "caneca de fundo preto" e CMT. Amostras de leite foram colhidas para a análise de resíduos de antimicrobianos (dois mililitros) e exame microbiológico. Todas as avaliações foram realizadas em amostras individuais por quarto e colhidas em duplicatas.

As amostras de ambas as colheitas (secagem e pós-parto) foram mantidas sob refrigeração até o encaminhamento ao laboratório e congeladas até o momento de sua análise.

\subsubsection{Diagnóstico do processo inflamatório}

Para diagnóstico da mastite clínica utilizou-se o teste da "caneca de fundo preto" que consistiu na retirada dos 3 a 4 primeiros jatos de leite, contrastando-os com uma superfície de fundo preto, com a finalidade de observar a presença de alterações no leite, tais como grumos e coágulos, pus, sangue ou leite aquoso.

O teste foi interpretado segundo os diferentes escores observados nos primeiros jatos de leite: 
$\checkmark$ Escore zero: leite normal (ausência de partículas).

$\checkmark$ Escore um: leite ligeiramente descolorido, com presença de grumos finos e delicados.

$\checkmark$ Escore dois: leite com muitos grumos.

$\checkmark$ Escore três: secreções não semelhantes ao leite, apresentando pus e/ou sangue e/ou fibrina, ou ainda aspecto viscoso, similar ao colostro (WATANABE, 1999).

Para diagnóstico dos casos subclínicos utilizou-se o CMT, teste capaz de detectar a ocorrência de mastite subclínica pelo aumento de células somáticas por mililitros de leite. De cada glândula mamária foi colhida uma amostra de dois mililitros de leite à qual foi adicionado, na mesma proporção, um detergente aniônico (alquil-lauril sulfato de sódio) capaz de emulsionar os lipídios das membranas dos leucócitos presentes no leite, com conseqüente liberação do material nucléico.

A geleificação da mistura do leite com o reativo proporcional à quantidade de células presentes foi classificada em diferentes escores, correspondentes à intensidade do processo inflamatório. O teste do CMT foi interpretado em escores: negativo, traço, 1, 2 ou 3, de acordo com a ausência ou o aumento da viscosidade da mistura. Foram considerados como casos de mastite subclínica, glândulas que apresentaram escore traço, 1, 2 ou 3 (SCHALM \& NOORLANDER, 1957).

O CMT é usado mundialmente para o diagnóstico de mastite subclínica, tendo a vantagem de poder ser empregado no próprio rebanho, no momento em que os animais são ordenhados (SCHALM \& NOORLANDER, 1957). 
No momento da secagem, não foram detectados casos de mastite clínica. Porém, durante o período seco, os animais que apresentaram mastite clínica foram identificados, tratados novamente com outro princípio ativo e excluídos do experimento.

\subsubsection{Identificação dos agentes causais da mastite}

O exame microbiológico foi realizado para identificar os agentes causais da mastite. Antes da colheita, o quarto foi lavado com água e solução desinfetante (cloro), seco com papel toalha descartável e individual e submetido à anti-sepsia com algodão embebido em álcool iodado (1000ml de álcool 70\% : 20ml iodo 2,5\%). A seguir, foram colhidos dois mililitros de leite em frascos estéreis $(16 \times 160 \mathrm{~mm})$ de cada glândula mamária, individualmente.

No laboratório, as amostras foram cultivadas em ágar sangue de carneiro incubadas em aerobiose a $37^{\circ} \mathrm{C}$ por 72 horas com leituras 24 , 48 e 72 horas, em ágar Sabouraud com cloranfenicol (100mg/l) e ágar MacConkey, sendo incubadas a $37^{\circ} \mathrm{C}$ por 48 horas. As técnicas microbiológicas para a identificação das bactérias foram empregadas conforme descrito por MURRAY et al., (1999).

\subsubsection{Detecção de resíduos de antimicrobianos}

As análises para detecção de resíduos de antimicrobianos foram realizadas através do teste microbiológico comercial, Delvotest ${ }^{\circledR} \mathrm{SP}$. O Delvotest ${ }^{\circledR} \mathrm{SP}$ é um teste de difusão que mede a inibição do crescimento bacteriano. É apresentado em ampolas contendo meio de cultura sólido com indicador de $\mathrm{pH}$ e, Bacillus stearothermophilus var. calidolactis na forma esporulada (Figura 1) . 


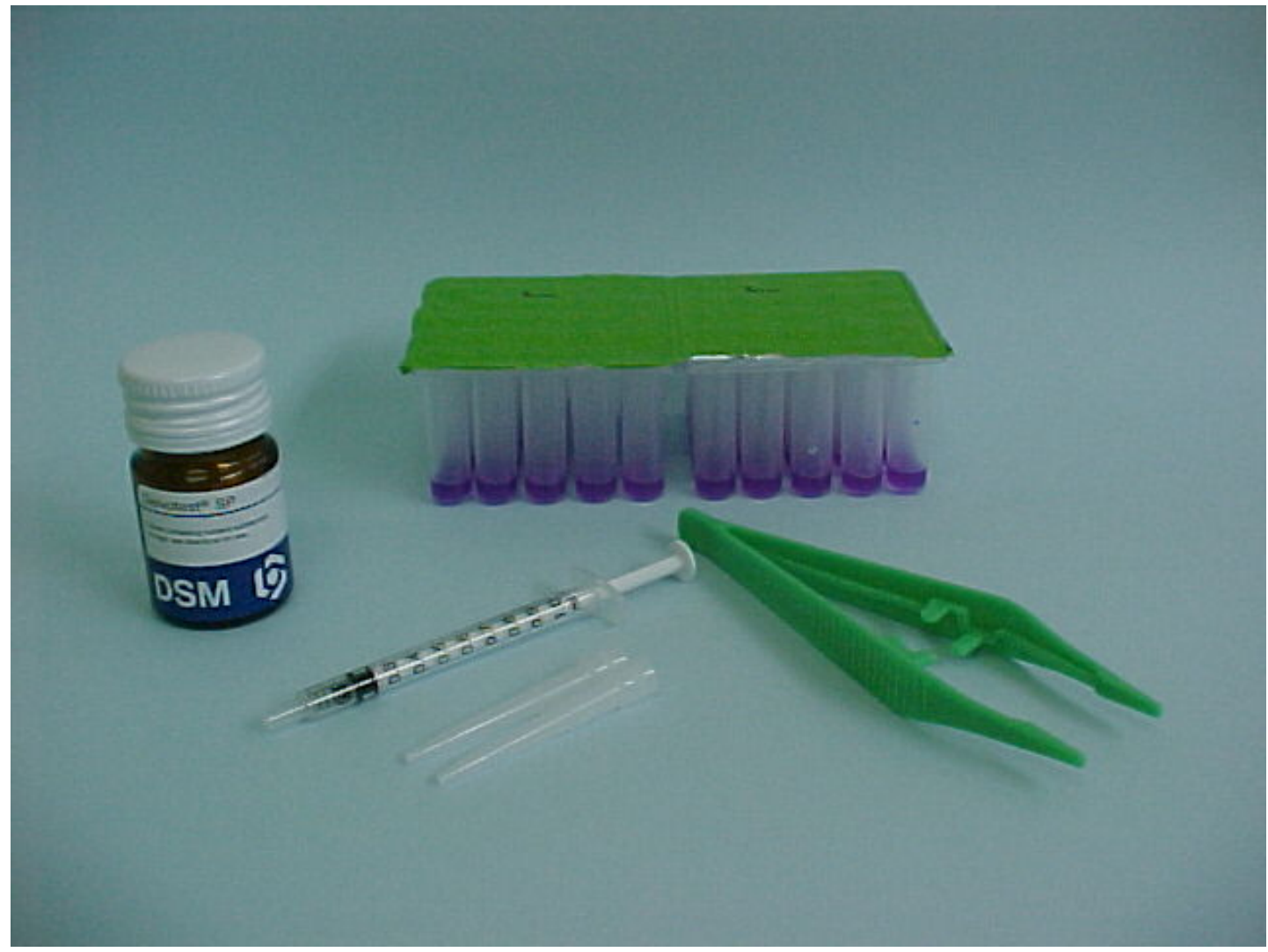

Figura 1 - Teste microbiológico comercial Delvotest ${ }^{\circledR} \mathrm{SP}$ utilizado no experimento para detectar resíduo de antimicrobianos no leite. Pirassununga, São Paulo. 2003

O teste obedece à seguinte metodologia: (1) - abertura das ampolas (Delvotest ${ }^{\circledR} \mathrm{SP}$ ) com a retirada da tampa de alumínio, (2) - adição da pastilha nutriente (glucose), (3) - adição de 0,1 mililitros das amostras de leite a serem analisadas (Figura 2), (4) - incubação das ampolas em banhomaria a $64^{\circ} \mathrm{C} \pm 0,5^{\circ} \mathrm{C}$ por duas horas e cinqüenta minutos, (5) - realização da leitura (Figura 3). 


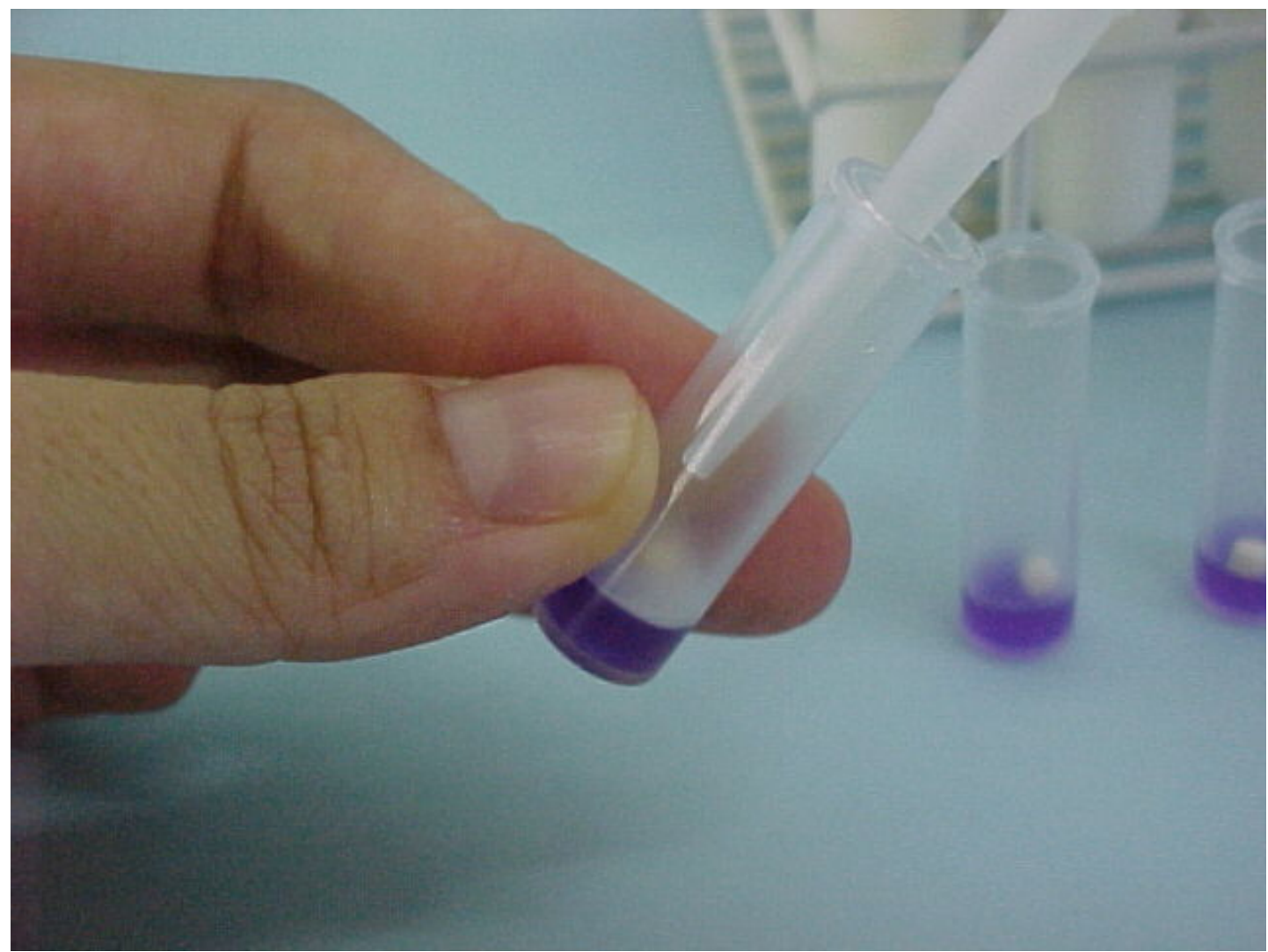

Figura 2 - Adição de 0,1 mililitros da amostra de leite na ampola já contendo a pastilha nutriente de glicose. Pirassununga, São Paulo. 2003 


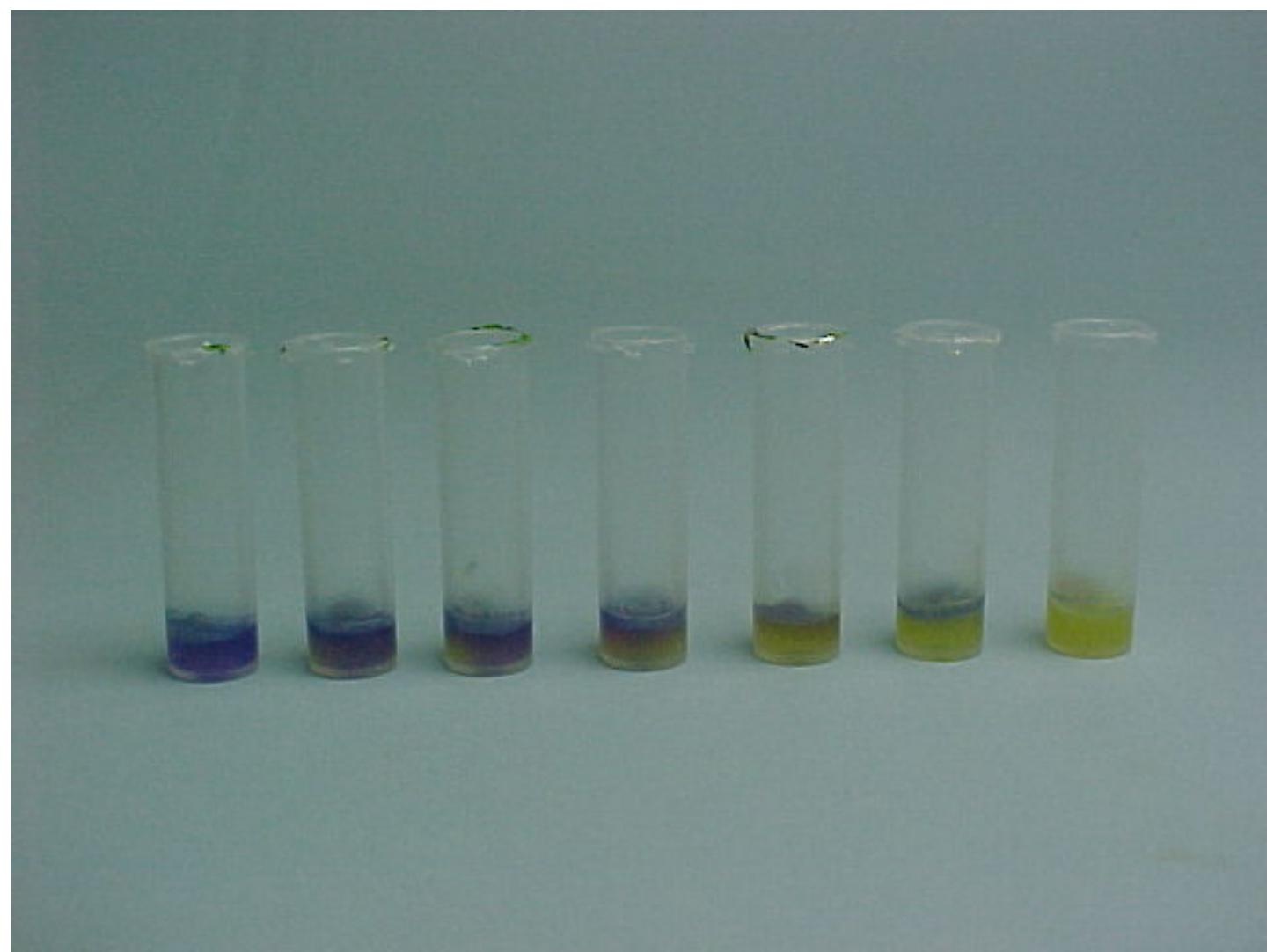

Figura 3 - Realização da leitura das amostras após a incubação no banho Maria por duas horas e cinqüenta minutos. Pirassununga, São Paulo. 2003

Após o período de incubação, ácido suficiente é produzido pelo crescimento das bactérias que utilizam a glicose. A alteração da cor do indicador de $\mathrm{pH}$ de púrpura para amarelo, indica uma amostra livre de antimicrobianos. Se, no entanto, o crescimento da bactéria for retardado ou inibido, não ocorre à acidificação do meio e este permanece púrpura. A coloração intermediária entre amarelo e púrpura também é considerada positiva para resíduo de antibiótico. O controle negativo foi feito com leite livre de substâncias inibidoras e o controle positivo, com amostra de leite contendo antibiótico (Figura 3).

Para anular a ocorrência de resultados falso-positivos, pela interferência de substâncias antimicrobianas naturais do leite, as amostras foram aquecidas a $80^{\circ} \mathrm{C}$ por 5 minutos em banho-maria, previamente à execução do teste. 
As ampolas do teste foram mantidas sob refrigeração à temperatura de aproximadamente $4^{\circ} \mathrm{C}$, como recomendado pelo fabricante. No momento da utilização, permaneceram à temperatura ambiente, apenas as ampolas a serem utilizadas.

\subsubsection{Análise Estatística}

A análise estatística foi realizada utilizando-se o "Software Instat GRAPHPAD", através do teste não paramétrico para probabilidades exatas de Fisher. Este teste segundo JEKEL et al., (1999) é usado para análise bivariada de dados não paramétricos dicotômicos e nominais. Os dados foram arranjados em uma tabela $2 \times 2$ e o objetivo foi testar a hipótese nula de que as variáveis a serem analisadas eram independentes.

As hipóteses no presente estudo foram:

$H_{0}=$ A presença de resíduo de antimicrobianos no leite de vacas tratadas no período seco (Terapia da Vaca Seca) é independente das variáveis estudadas.

Variáveis estudadas:

i. Do tipo de medicamento utilizado na secagem;

ii. Da duração do período seco;

iii. Do volume de produção de leite na secagem e da média de produção de leite na lactação;

iv. Da ocorrência e intensidade do processo inflamatório (CMT);

v. Da presença infecção na glândula mamária;

vi. Do intervalo de tempo entre tratamento e colheita das amostras (ITC);

vii. Do número de quartos mamários resíduo positivos.

$H_{1}=$ A presença de resíduo de antimicrobianos no leite de vacas tratadas no período seco (Terapia da Vaca Seca) é dependente de pelo menos uma destas variáveis. 


\section{RESULTADOS E DISCUSSÃO}

O tratamento com antibiótico é o principal método utilizado para a eliminação das infecções existentes, sendo que o sucesso da terapia depende da difusão do medicamento em toda a área infectada no quarto mamário e da concentração mínima por tempo suficiente para eliminar todos os microrganismos causadores da infecção (NICKERSON, 2002). Diversas pesquisas demonstram que o período de tratamento de 3 a 5 dias durante a lactação é mais efetivo, COSTA et al., (2001) em estudo comparando mais de 900 diferentes tipos de tratamentos, concluíram que tratamentos mais prolongados tornam-se anti-econômico e improcedente. Mesmo assim, o risco potencial da presença de resíduos de antimicrobianos no leite de consumo, faz com que o descarte do leite durante e após o tratamento de animais em lactação seja uma medida compulsória representando, portanto, um elevado custo na produção leiteira.

Com o objetivo de minimizar o perigo dos resíduos de antimicrobianos no leite, foram formulados medicamentos para uso no período de interrupção da lactação, conhecido como tratamento de vaca seca. Assim sendo, além de apresentar objetivos terapêuticos e profiláticos de mastite o tratamento de vaca seca é uma alternativa que visa também evitar resíduo de antibiótico no leite. Entretanto, com a evolução tecnológica para atuar na prevenção de infecções na glândula mamária durante todo o período seco, foram utilizadas concentrações e principalmente veículos (excipientes) que prolongam a persistência do antibiótico na glândula mamária, o que conseqüentemente passou a constituir um risco à saúde dos consumidores, devido à possível presença de resíduos no leite de consumo. 
Devido à relevância do assunto, estudos na literatura têm avaliado a presença de resíduos de antimicrobianos no leite, e alguns autores analisaram fatores relacionados ao animal, como, nível de produção e estado fisiológico da glândula e a influência sobre a eliminação de resíduos no leite (FOLEY et al., 1949; MERCER et al., 1970). Outros autores relataram que a mastite pode afetar a eliminação destes resíduos (MORETAIN \& BOISSEAU, 1993; COSTA, 1999; RAIA, 2001).

Raia (2001), desenvolveu estudo abrangente avaliando diversos fatores possivelmente relacionados ao risco de ocorrência de antimicrobianos no leite. Na pesquisa foi verificada a ocorrência de resíduos de antimicrobianos em 60 amostras de leite de tanques resfriadores de propriedades leiteiras e individualmente de 135 vacas em lactação com e sem processo inflamatório na glândula mamária. No estudo foi verificada correlação entre o aumento da freqüência de mastite clínica e a ocorrência de resíduo de antimicrobiano no tanque resfriador ( $r=1$ teste de Spearman). Foi avaliado o aumento do período de carência, a persistência de resíduos no leite, a via de administração, e o tipo de antimicrobiano em glândulas com e sem processo inflamatório. Foram detectados resíduos além do período de carência estipulado pelos fabricantes, tanto nos animais tratados por via sistêmica quanto naqueles tratados por via intramamária. Tal fato foi observado em relação a todos os grupos tratados com diferentes antimicrobianos ( $\beta$-lactâmicos, aminoglicosídeos, tetraciclinas e sulfas) variando de 11 a $60 \%$ das amostras analisadas. Após 72 horas da aplicação de medicamento por via sistêmica, houve diferença significativa $(p \leq 0,05$, Fisher) entre as amostras de animais com mastite e as de animais com ausência de processo inflamatório, indicando uma maior persistência de resíduo nas amostras de animais com mastite. Em todas as avaliações foi utilizado o teste microbiológico comercial (Delvotest ${ }^{\circledR} \mathrm{SP}$ ). 
Pesquisas brasileiras recentes (COELHO \& COSTA, 2002; COELHO, 2003) destacaram a influência de fatores idiossincrásicos, entre outros, na ocorrência de resíduos de antimicrobianos no leite de glândulas mamárias não tratadas (contralaterais, ipsolaterais e diagonais) de animais em lactação tratados por via intramamária, com antimicrobianos próprios para tratamento em lactação. Ficou demonstrado que a ocorrência de resíduo de antimicrobianos no leite de glândulas não tratadas (27\% dos 143 animais avaliados) adjacentes às tratadas por via intramamária, é um risco real e importante.

Apesar de um dos objetivos da terapia da vaca seca ser o de evitar resíduos de antimicrobianos no leite, poucas pesquisas têm sido direcionadas para a avaliação deste risco.

No presente estudo foram avaliadas glândulas mamárias quanto à presença de resíduos de antimicrobianos no leite no período pós-parto, de animais submetidos à terapia antimicrobiana na secagem.

Verificou-se que a ocorrência de quartos positivos referentes à propriedade A, B e C para resíduo de antimicrobianos foram 18\%, 22,2\% e 26,5\% respectivamente, obtendo-se uma média de $19,37 \%$ de positividade nas amostras analisadas (Tabela 7). A taxa de positividade encontrada neste experimento foi considerável, sugerindo que diversos fatores podem interferir na excreção dos medicamentos no leite, mesmo após o período de descarte recomendado, independente do tipo de manejo e práticas de ordenha utilizadas nas propriedades leiteiras.

$\mathrm{Na}$ Tabela 7 estão apresentados os resultados quanto à influência do tipo de medicamento (grupo farmacológico) utilizado na terapia de secagem, na ocorrência de resíduos de antimicrobianos no leite. 
Tabela 7 - Avaliação da influência do tipo de medicamento utilizado na secagem, na ocorrência de resíduos de antimicrobianos no leite. Pirassununga, São Paulo. 2003

\begin{tabular}{lcccc}
\hline Propriedades & Grupo & Quartos & Quartos R+ & $\%$ \\
\hline \multirow{3}{*}{ Propriedade A } & Grupo 1 & 68 & 15 & 22,1 \\
& Grupo 2 & 82 & 12 & 14,6 \\
& Grupo 3 & 78 & 14 & 17,9 \\
\cline { 2 - 5 } & Total & $\mathbf{2 2 8}$ & $\mathbf{4 1}$ & $\mathbf{1 8 , 0}$ \\
\hline \multirow{3}{*}{ Propriedade B } & Grupo 2 & 16 & 4 & 25,0 \\
& Grupo 3 & 11 & 2 & 18,2 \\
\cline { 2 - 5 } & Total & $\mathbf{2 7}$ & $\mathbf{6}$ & $\mathbf{2 2 , 2}$ \\
\cline { 2 - 5 } & Grupo 2 & 24 & 6 & 25,0 \\
Propriedade C & Grupo 3 & 10 & 3 & 30,0 \\
\cline { 2 - 5 } & Total & $\mathbf{3 4}$ & $\mathbf{9}$ & $\mathbf{2 6 , 5}$
\end{tabular}

Quartos: quartos mamários; Quartos R+: quartos mamários positivos para resíduo de antimicrobianos; \%: porcentagem de animais positivos para resíduo de antimicrobianos; Grupo 1: Cefalônio anidro; Grupo 2: hidroiodeto de penetamato + penicilina benetamina + sulfato de framicetina; Grupo 3: benzilpenicilina procaína + monoidrato sódico de nafcilina + sulfato de diidroestreptomicina.

Em estudo conduzido por COSTA et al., (2000) comparando medicamentos próprios para tratamento de mastite durante a lactação, os resultados de positividade para resíduo entre antimicrobianos do grupo dos $\beta$-lactâmico (cefalosporinas) apresentaram maior positividade para resíduos, que os aminoglicosídeos, verificando neste estudo diferença entre os grupos farmacológicos. No presente estudo, de acordo com a Tabela 7 a ocorrência de resíduos de antimicrobianos nas propriedades A, B e C foi de $18 \%$, $22,2 \%$ e 26,5\% respectivamente. Entretanto, não foram detectadas diferenças estatísticas entre os grupos farmacológicos nas propriedades estudadas. 
A Figura 4 ilustra a porcentagem de glândulas mamárias positivas e negativas para a presença de resíduos de antimicrobianos encontrada em cada propriedade avaliada.

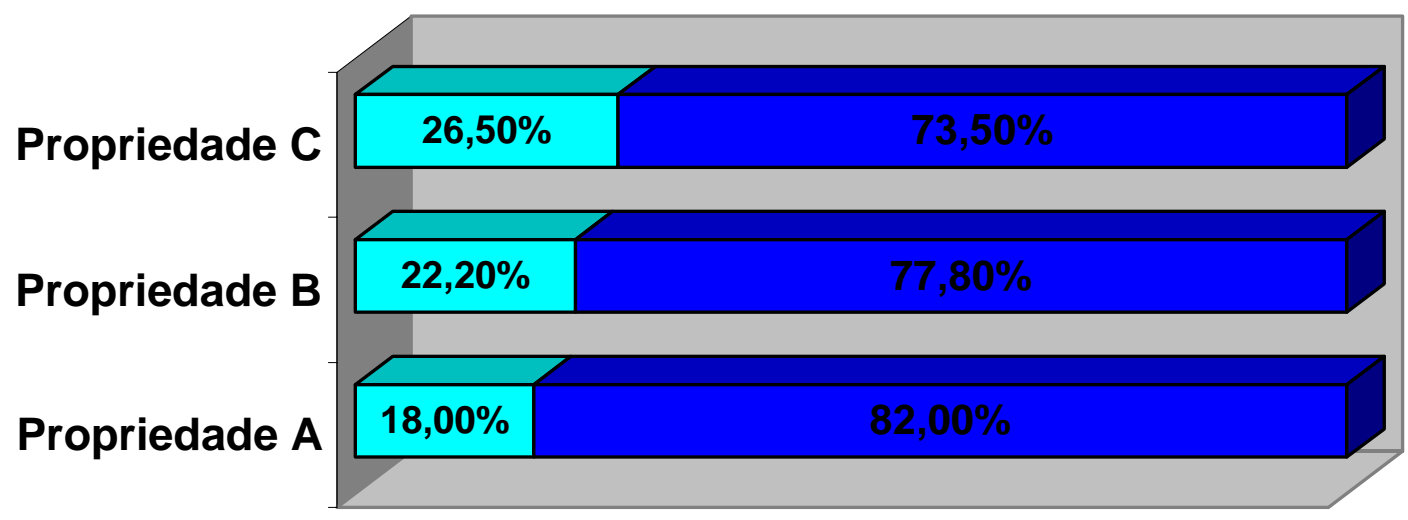

\section{Quartos Positivos Q Quartos Negativos}

Figura 4 - Porcentagem de glândulas mamárias positivas e negativas para a presença de resíduos de antimicrobianos, encontrada em cada propriedade avaliada. Pirassununga, São Paulo. 2003

JOHNSON et al., (1977), trabalhando com duas infusões intramamárias (cloxacilina e penicilina) no período de 10 a 12 dias antes do parto previsto, concluíram que, se fossem seguidas as recomendações quanto ao período de excreção de cada medicamento e praticando o descarte do leite nos primeiros dias pós-parto, não ocorreriam problemas de resíduos no leite.

OLIVER et al., (1992), trabalhando com novilhas primíparas, administraram cloxacilina e cefapirina sódica sete dias antes do parto previsto e avaliaram o início da lactação destes animais quanto à ocorrência de resíduos de antibióticos no leite. A cloxacilina foi encontrada em 17,4\% das amostras obtidas meio dia pós-parto, mas negativas nos dias três e 10 pós-parto; por outro lado a cefapirina resultou em resíduos em 84,7\%, 28,2\% e $0 \%$ das amostras obtidas nos dias $1 / 2$, três e 10 , respectivamente. Uma vez 
que os medicamentos utilizados por estes autores (JOHNSON et al., 1977; OLIVER et al., 1992) são medicamentos para uso em lactação e não medicamento para tratamento de vaca seca, os resultados obtidos diferem dos obtidos no presente estudo, demonstrando a menor persistência na glândula mamária em decorrência da formulação em excipientes diferentes.

A importância do excipiente no tempo de eliminação de resíduos de antimicrobianos foi avaliada por ANDRADE et al., (1993), que estudaram o padrão de liberação de antibióticos no leite de vacas com mastite tratadas por via intramamária com medicação única contendo penicilina e estreptomicina, em veículo oleoso ou aquoso. As formulações oleosas apresentaram porcentagens maiores de glândulas liberando resíduo de antibiótico do que as de base aquosa. As médias globais para as formulações foram de 68,2\% para as oleosas e de 59,4\% para as aquosas.

Na Tabela 8 estão os resultados da influência da duração do período seco na ocorrência de resíduos de antimicrobianos no leite em relação às amostras colhidas na propriedade $A$.

Tabela 8 - Avaliação quanto à influência da duração do período seco na ocorrência de resíduos de antimicrobianos no leite referentes à Propriedade A. Pirassununga, São Paulo. 2003

\begin{tabular}{cccc}
\hline Grupo & Quartos & Quartos R + & $\%$ \\
\hline PS $<60$ dias & 55 & 16 & $29,1^{\mathrm{a}}$ \\
PS de 60 a 70 dias & 103 & 20 & $19,4^{\mathrm{a}}$ \\
PS $>$ que 70 dias & 70 & 5 & $7,1^{\mathrm{b}}$ \\
\hline
\end{tabular}

PS: Período Seco; Quartos: quartos mamários; Quartos R+: quartos mamários positivos para resíduo de antimicrobianos; \%: porcentagem de animais positivos para resíduo de antimicrobianos. ${ }^{a}$ Valores com as mesmas letras não diferem estatisticamente entre si pelo Teste de Fisher a $5 \%$.

Pela análise dos resultados apresentados na Tabela 8 verifica-se que a ocorrência de antimicrobianos foi significativamente maior $(P=0,0015)$ quando o período seco dos animais foi menor que 60 dias $(29,1 \%)$. E quanto 
mais longo o período seco (> 70 dias) menor a ocorrência de resíduos no leite $(7,1 \%)(P=0,0278)$. Tais resultados são esperados, uma vez que os períodos de persistência nos tratamentos de vaca seca mais atuais são habitualmente de cerca de 60 dias, devido este ser o período seco reconhecido nacional e internacionalmente como o mais adequado. Entretanto fato que surpreende é a detecção de $7,1 \%$ de resíduos de antimicrobianos em glândulas mamárias de animais com mais de 70 dias.

HILL \& SMALL (1985) utilizaram quatro formulações diferentes à base de $\beta$-lactâmicos em quatro períodos: (1) na secagem, (2) 6 semanas da data prevista do parto, (3) 4 semanas da data prevista do parto e (4) tratamento na secagem mais um produto para vaca em lactação 3 semanas da data prevista do parto. Das 30 amostras analisadas, 29 delas foram negativas após o quarto dia pós-parto. Foi detectada a presença de resíduo nas amostras em que foi aplicado medicamento 6 semanas da data prevista do parto. O autor concluiu que o risco da presença de resíduo de antimicrobiano é maior quando o período seco for menor que 42 dias.

FONSECA E SANTOS (2000) trabalharam com 34 vacas tratadas na secagem com Gentamicina Vaca Seca $(400 \mathrm{mg}$ ) em três períodos distintos: (A) tratamento na secagem (60 dias), (B) tratamento na secagem mais uma segunda infusão 30 dias antes da data prevista do parto, (C) tratamento na secagem mais uma segunda infusão 15 antes da data prevista do parto. Foram colhidas amostras de leite destes animais até que estas se apresentassem isentas de resíduo. Os animais que receberam o tratamento A não apresentaram resíduo de antimicrobianos no leite comercializável, no entanto os animais que receberam os tratamentos B e $C$ apresentaram resíduo durante seis e 12 dias consecutivos respectivamente. Os autores afirmaram, que não é necessário o descarte do leite quando a duração do período seco for de 60 dias, pois o risco de resíduo de antimicrobianos no leite seria menor. No entanto, confirmaram a preocupação com a presença de resíduos que pode ocorrer em vacas que por alguma razão têm o parto 
antecipado, ou são ordenhadas acidentalmente durante o período seco. Por outro lado, COSTA et al., (1999) verificaram em tratamentos de mastite com produtos a base de gentamicina em animais em lactação, uma menor porcentagem de ocorrência de resíduo, quando comparado com outros antimicrobianos, o que pode justificar os resultados obtidos pelos autores citados que utilizaram este aminoglicosídeo no tratamento de vaca seca.

OLIVER et al., (1984), trabalharam com diferentes formulações na secagem, penicilina procaína, novobiocina, cloxacilina e cefapirina. No dia do parto e 4 dias após o parto colheram amostras compostas dos animais e concluíram que os animais com período seco maior que 45 dias apresentaram ausência de resíduo de antimicrobianos no leite.

Os resultados obtidos no presente estudo demonstraram a importância da duração do período seco na presença de resíduos de antimicrobianos no leite de consumo. No entanto, ressalta-se que somente quando o período seco foi maior que 70 dias o risco da presença de resíduo de antimicrobianos no leite foi menor, discordando dos demais autores (HILL \& SMALL, 1985; FONSECA E SANTOS, 2000; OLIVER et al., 1984). Por outro lado os resultados obtidos estão em consonância com JONES \& SEYMOUR (1988), que defendem a idéia de que os produtores devem ser encorajados a tratar suas vacas secas, mas animais com período seco curto devem ser testados quanto à presença de resíduos de antibióticos aos quatro dias pós-parto, ou quando acabar o período de colostro (limpeza do leite) e descartar o leite até o teste apresentar-se negativo.

A porcentagem de $19,4 \%$ de resíduos em animais com período seco entre 60 a 70 dias é resultado que deve ser destacado, pois contraria a idéia de que o risco de resíduo após o parto ocorreria particularmente em animais com período seco curto ou devido à antecipação de parto. Uma vez que estatisticamente não diferiu dos resultados dos animais com período seco curto, isto é, menor que 60 dias (Tabela 8), diferindo estatisticamente apenas do grupo com mais de 70 dias. Portanto, o período seco preconizado 
como ideal por proporcionar à glândula mamária tempo necessário para involução e se preparar para a colostrogênese e nova lactação (60 dias), não constitui garantia de isenção de resíduos no leite no pós-parto, reforçando que provavelmente a evolução tecnológica dos produtos modernos destinados ao tratamento de vaca seca, de uma forma, ao ampliar a proteção da glândula mamária durante todo o período seco paralelamente, também aumentaram a possibilidade de resíduo, além do período de 60 dias.

HILLERTON et al., (1999) citam que no quarto dia pós-parto não há evidências de inibidores naturais no leite que poderiam acarretar em falsos positivos. As colheitas nos animais deste experimento foram realizadas em média sete dias após o parto, período em que, segundo este autor, não deveriam aparecer resíduos de antimicrobianos no leite, bem como inibidores naturais. Além disso, todas as amostras foram submetidas a aquecimento prévio a $80^{\circ} \mathrm{C}$ por cinco minutos, de acordo com 0 demonstrado por RAIA (2001) e outros autores internacionais, sendo suficiente para eliminar as reações falso-positivas.

RAIA (2001), avaliou a interferência do processo inflamatório sobre a positividade do teste microbiológico (Delvotest ${ }^{\circledR} \mathrm{SP}$ ) quanto à presença de inibidores naturais para excluir qualquer chance de erro. Em amostras de leite de 46 quartos mamários de animais em lactação não tratados foram observadas reações falso-positivas em 33\% dos quartos com mastite clínica e em $18 \%$ dos casos com mastite subclínica. Por outro lado, em quartos sem mastite, ou seja, na ausência do processo inflamatório, não ocorreram reações falso positivas, demonstrando que os inibidores naturais estão presentes quanto maior for a intensidade do processo inflamatório.

Na Tabela 9 estão apresentados os resultados da relação entre a duração do período seco e os grupos de tratamento. Constata-se a partir destes dados que a duração do período seco é realmente importante, e 
influencia na excreção de resíduo de antimicrobianos no leite, independentemente do medicamento utilizado.

Tabela 9 - Avaliação da duração do período seco (dias) em relação aos grupos farmacológicos utilizados no tratamento de secagem. Pirassununga, São Paulo. 2003

\begin{tabular}{ccccc}
\hline Período Seco & Grupo & Quartos & Quartos R + & $\%$ \\
& tratamento & & 3 & 18,75 \\
PS $<$ 60 dias & Grupo 1 & 16 & 12 & 25,00 \\
PS de 60 a 70 dias & Grupo 1 & 48 & 0 & 0 \\
\hline Total & Grupo 1 & 4 & $\mathbf{1 5}$ & $\mathbf{2 2 , 1}$ \\
\hline PS $<60$ dias & Grupo 2 & 16 & 5 & 31,25 \\
PS de 60 a 70 dias & Grupo 2 & 35 & 7 & 20,00 \\
PS $>70$ dias & Grupo 2 & 31 & 0 & 0 \\
\hline Total & & $\mathbf{8 2}$ & $\mathbf{1 2}$ & $\mathbf{1 4 , 6}$ \\
\hline PS $<60$ dias & Grupo 3 & 23 & 8 & 34,78 \\
PS de 60 a 70 dias & Grupo 3 & 20 & 1 & 5,00 \\
PS $>$ 70 dias & Grupo 3 & 35 & 5 & 14,29 \\
\hline Total & & $\mathbf{7 8}$ & $\mathbf{1 4}$ & $\mathbf{1 7 , 9}$ \\
\hline
\end{tabular}

PS: período seco; Quartos: quartos mamários; Quartos R+: quartos mamários positivos para resíduo de antimicrobianos; Grupo 1: cefalônio anidro; Grupo 2: hidroiodeto de penetamato + penicilina benetamina + sulfato de framicetina; Grupo 3: benzilpenicilina procaína + monoidrato sódico de nafcilina + sulfato de diidroestreptomicina.

$\mathrm{Na}$ Tabela 10 estão apresentados os resultados da relação entre o volume de leite médio produzido durante a lactação e a produção de leite no dia da secagem na ocorrência de resíduos de antimicrobianos no leite. A média de leite produzido durante a lactação dos animais foi $31,37 \mathrm{Kg} / \mathrm{dia}$ e na secagem foi $16,93 \mathrm{Kg} / \mathrm{dia}$. 
Tabela 10 - Influência do volume de produção de leite média durante a lactação e a produção no dia da secagem na ocorrência de resíduos de antimicrobianos na Propriedade A. Pirassununga, São Paulo. 2003

\begin{tabular}{cccc}
\hline Produção Secagem & Quartos & Quartos R & $\%$ \\
\hline$<20 \mathrm{Kg} /$ dia & 124 & 19 & 15,3 \\
$>20 \mathrm{Kg} /$ dia & 104 & 22 & 21,2 \\
\hline Produção na lactação & Quartos & Quartos R + & $\%$ \\
\hline$<20 \mathrm{Kg} /$ dia & 81 & 15 & 18,5 \\
$>20 \mathrm{Kg} /$ dia & 147 & 26 & 17,7 \\
\hline
\end{tabular}

Quartos: quartos mamários; Quartos R+: quartos mamários positivos para resíduo de antimicrobianos; \%: porcentagem de animais positivos para resíduo de antimicrobianos; $\mathrm{Kg}$ : quilogramas de leite.

Não foram detectadas diferenças estatisticamente significativas entre o volume de produção médio na lactação e o volume de leite no dia da secagem na ocorrência de resíduo de antimicrobianos no leite.

ZIV et al., (1974), administraram penicilina G e cloxacilina em vacas secas produzindo 2 a 3 vezes mais leite na secagem do que outras vacas, e observaram que a excreção do antibiótico nos animais de maior produção foi 10 a 100 vezes mais lenta do que nos animais de menor produção. Já em estudo realizado por JOHNSON et al., (1977), houve um efeito diluição, pois animais de maior produção não apresentaram resíduos de antimicrobianos no leite.

EGAN \& MEANEY (1985), trabalharam com animais produzindo acima de $10 \mathrm{~kg}$ e abaixo de $10 \mathrm{Kg}$ de leite/dia, e obtiveram maiores percentuais de excreção de resíduos de antimicrobianos em animais de menor produção.

Como também, JONES \& SEYMOUR (1988), observaram que vacas de alta produção e ordenhadas três vezes ao dia tenderam a 
apresentar resultados negativos mais rapidamente, devido à excreção mais acelerada da droga. SEYMOUR et al., (1988), testando amostras de leite para resíduos de antibióticos em períodos adicionais ao de carência recomendado em vacas em lactação, demonstraram que não ocorreu variação quanto à via de administração, dias de tratamento, peso dos animais, número de lactações e produção diária de leite na persistência da excreção de drogas. FAGUNDES et al., (2000) afirmaram que produções de quantidades escassas de leite determinam largas permanências de antibióticos no úbere.

Deve-se ressaltar que como em trabalhos mais antigos (NATZKE et al., (1975); ZIV et al., (1974), EGAN \& MEANEY (1985)) as médias de produção dos animais eram inferiores quando comparada com as médias trabalhadas atualmente torna difícil a comparação por volume de produção. Destacando-se que mesmo entre os trabalhos mais antigos da década de 70 os resultados são contraditórios (ZIV et al., (1974) e JOHNSON et al., (1977)), houve um efeito diluição, pois animais de maior produção não apresentaram resíduos de antimicrobianos no leite.

$\mathrm{Na}$ Tabela 11 estão dispostos os resultados comparando a duração do período seco (dias) e o volume de produção de leite na secagem, na ocorrência de resíduos de antimicrobianos. Verifica-se que quando o período seco foi menor que 70 dias a taxa de excreção de medicamento foi maior, mesmo com a produção acima de $20 \mathrm{Kg}$ no momento da secagem, evidenciando assim, a importância da duração do referido período. Sugerindo que o fator volume de produção não constitui fator relevante na persistência de resíduos de antimicrobianos. 
Tabela 11 - Influência da duração do período seco em relação ao volume de produção de leite na secagem na ocorrência de resíduos de antimicrobianos no leite. Pirassununga, São Paulo. 2003

\begin{tabular}{cccc}
\hline Grupo & Quartos & Quartos R + & $\%$ \\
\hline$<70$ dias $<20 \mathrm{Kg}$ & 89 & 14 & 15,7 \\
$>70$ dias $<20 \mathrm{Kg}$ & 39 & 5 & 12,8 \\
$<70$ dias $>20 \mathrm{Kg}$ & 88 & 22 & 25,0 \\
$>70$ dias $>20 \mathrm{Kg}$ & 12 & 0 & -- \\
\hline
\end{tabular}

PS: Período Seco; Quartos: quartos mamários; Quartos R+: quartos mamários positivos para resíduo de antimicrobianos; \%: porcentagem de animais positivos para resíduo de antimicrobianos.

Na Tabela 12 estão apresentados os resultados da ocorrência e intensidade do processo inflamatório e sua relação com a presença de resíduos de antimicrobianos no leite analisado na propriedade $A$. Não foram detectadas diferenças estatisticamente significativas.

Tabela 12 - Avaliação da influência da ocorrência e intensidade do processo inflamatório na presença de resíduos de antimicrobianos no leite na propriedade A. Pirassununga, São Paulo. 2003

\begin{tabular}{cccc}
\hline CMT & Quartos & Quartos R & $\%$ \\
\hline Negativo & 94 & 24 & 25,5 \\
Positivo & 134 & 17 & 12,7 \\
\hline Total & $\mathbf{2 2 8}$ & $\mathbf{4 1}$ & $\mathbf{1 8 , 0}$ \\
\hline
\end{tabular}

CMT: Califórnia Mastite Teste; Quartos: quartos mamários; Quartos R+: quartos mamários positivos para resíduo de antimicrobianos; \%: porcentagem de animais positivos para resíduo de antimicrobianos.

Os resultados obtidos neste trabalho quanto à ocorrência e intensidade do processo inflamatório denota que $25,5 \%$ dos quartos positivos para resíduo de antimicrobianos foram negativos no teste do CMT (CCS < que 100.000 células por ml). RUEGG \& TABONE (2000), trabalhando com vacas ao longo da lactação e com amostras dos tanques de mistura, com o objetivo de determinar a relação entre a CCS e a presença de resíduo de antimicrobianos, encontraram valores de CCS 
significativamente maiores (acima de 700.000 células por $\mathrm{ml}$ ) para amostras de leite com resíduo positivo. Eles perceberam com este estudo que o risco de resíduo de antimicrobiano é sete vezes maior em animais com alta contagem do que em animais com contagem abaixo de 250.000 células por $\mathrm{ml}$, o que discorda dos resultados obtidos neste trabalho em que não houve relação entre processo inflamatório e a ocorrência de resíduos no leite.

Em pesquisa recente realizada por COELHO \& COSTA (2002) e COELHO (2003), foi detectada influencia do processo inflamatório na ocorrência de resíduos. O grupo de animais tratados com mastite subclínica apresentou maior positividade para resíduo de antimicrobianos $(52,6 \%)$ em quartos não tratados adjacentes aos tratados. Este resultado segundo o autor reforça a recomendação de tratar casos de mastite subclínica com a terapia da vaca seca. MORETAIN \& BOISSEAU (1993); COSTA (1999) e RAIA (2001) também relataram que a mastite pode afetar a eliminação de resíduos de antimicrobianos no leite.

No presente trabalho, todos os animais que apresentaram mastite clínica durante o período seco e no início da lactação ou foram tratados para outras enfermidades, foram excluídos do experimento, para não haver interferência de outros medicamentos que não o do tratamento de vaca seca. Os animais testados não apresentaram evidência de processo inflamatório clínico no momento da colheita das amostras, e a relação entre CMT positivo e persistência de excreção do antimicrobiano no leite foi inversa, demonstrando que a presença de mastite subclínica neste trabalho, não interferiu na presença de resíduo de antimicrobiano no leite.

Na Tabela 13 estão dispostos os resultados quanto à presença de infecção intramamária no pós-parto na ocorrência de resíduos detectáveis de antimicrobianos no leite na propriedade $A$. Não foram detectadas diferenças estatísticas. De um total de 18 quartos (7,9\%) infectados no pósparto, apenas um quarto teve a presença de resíduo de antimicrobiano 
(5,5\%), demonstrando que não houve relação entre a ocorrência de resíduo de antimicrobiano e a presença de infecção intramamária.

Tabela 13 - Influência da presença infecção no período pós-parto na ocorrência de resíduos detectáveis de antimicrobianos no leite. Pirassununga, São Paulo. 2003

\begin{tabular}{cccc}
\hline Microrganismo & Quartos & Quartos R+ & $\%$ \\
\hline Staphylococcus sp. & 11 & 0 & 0,0 \\
Streptococcus sp. & 5 & 0 & 0,0 \\
Corynebacterium sp. & 2 & 1 & 50,0 \\
Positivo & $\mathbf{1 8}$ & $\mathbf{1}$ & $\mathbf{5 , 5}$ \\
Negativo & $\mathbf{2 1 0}$ & $\mathbf{4 0}$ & $\mathbf{1 9 , 0}$ \\
\hline
\end{tabular}

Quartos: quartos mamários examinados; Quarto R+: quartos mamários positivos para resíduo de antimicrobiano; \%: porcentagem de quartos mamários positivos para resíduo de antimicrobianos.

A Figura 5 ilustra a porcentagem de quartos positivos e negativos para a presença de microrganismos nos dois períodos de colheita de amostras, a pré-secagem e o pós-parto.

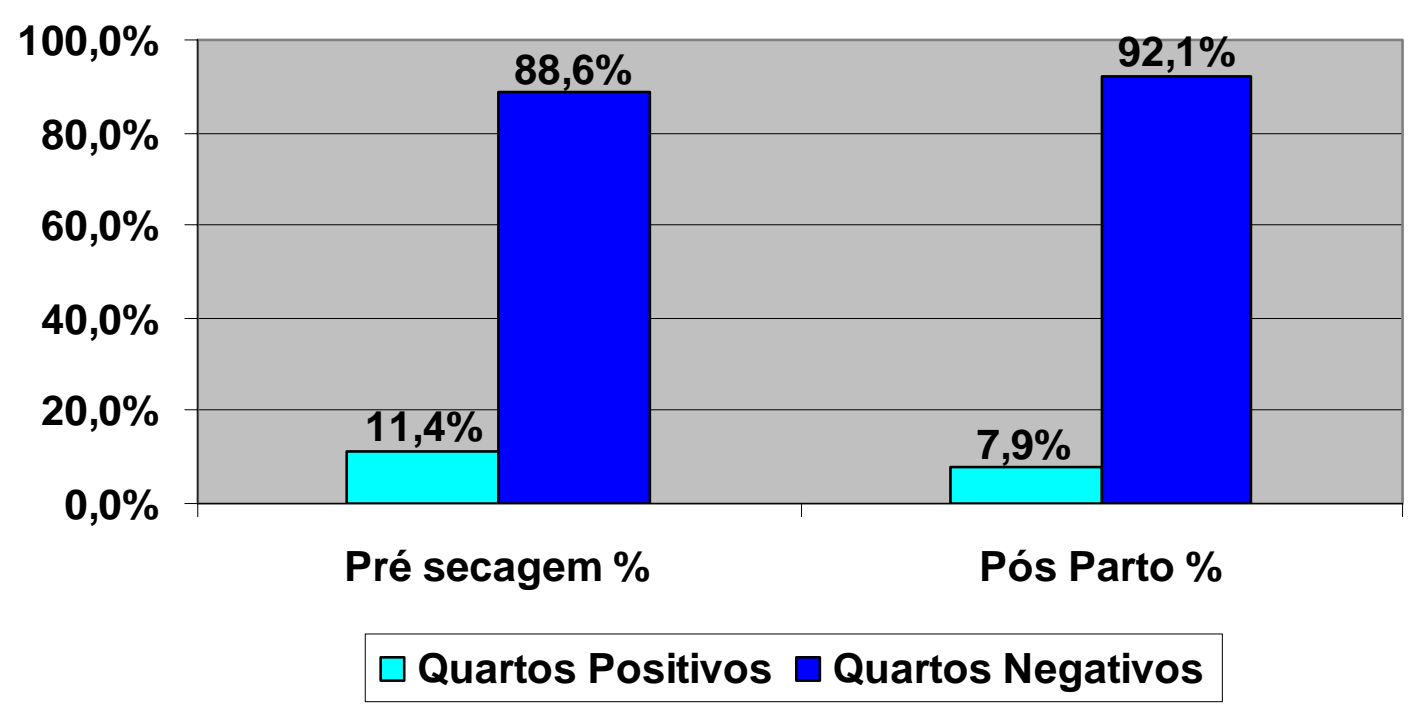

Figura 5 - Porcentagem de quartos avaliados na pré-secagem e no pósparto, positivos e negativos para a presença de infecção intramamária. Pirassununga, São Paulo. 2003 
COELHO (2003) que avaliou a influência das infecções intramamárias em animais em lactação na presença de resíduo de antimicrobianos no leite em quartos não tratados, não observou diferença estatística significativa em relação à positividade nos quartos após o tratamento.

A ação antimicrobiana dentro do tecido glandular mamário inflamado é diferente da que ocorre no tecido normal. Podem ocorrer variações no $\mathrm{pH}$ do leite dependendo se os microrganismos envolvidos são ou não fermentadores de lactose e, do número destes na glândula (COSTA, 1996). No presente estudo, de um total de 228 amostras colhidas no pósparto, 210 quartos (92,1\%) foram negativos para microrganismos patogênicos e somente 18 (7,9\%) apresentaram-se infectados no pós-parto, sendo que destes apenas um foi positivo para resíduo de antimicrobianos (Figura 5).

Por outro lado, como em tese, a presença de microrganismos patogênicos na glândula mamária poderia afetar o desempenho do teste utilizado, principalmente sendo este microbiológico. No entanto, em estudo conduzido por ANDREW (2001), em que foi avaliada a presença de microrganismos, observou-se que não há associação entre a taxa de infecção e o desempenho do teste de triagem.

OLIVER et al., (1984), administraram quatro produtos diferentes em vacas secas. Das 186 amostras colhidas no quarto dia pós-parto, quatro foram positivas para resíduo. A maioria, dos animais no experimento, apresentava período seco superior a 46 dias, sendo o intervalo tratamento colheita (ITC) em torno de 50 dias. Das amostras colhidas do primeiro leite de consumo, $96 \%$ das vacas que receberam tratamento foram negativas. No entanto, o autor recomenda sempre estar atento à excreção de medicamento além do tempo recomendado, sendo importante para não haver o risco de contaminação, principalmente, do tanque de pequena 
mistura. No presente estudo foi realizada uma análise em relação à influência do intervalo entre o tratamento e colheita das amostras (ITC) na ocorrência de resíduos de antimicrobianos no leite. Para ilustrar este aspecto, na Tabela 14 estão apresentados os resultados referentes às propriedades A e C.

Tabela 14- Influência do intervalo de tempo entre tratamento e colheita das amostras (ITC) na ocorrência de resíduos de antimicrobianos na Propriedade A e C. Pirassununga, São Paulo. 2003

\begin{tabular}{ccccc}
\hline Propriedade & ITC & Quartos & Quartos R + & $\%$ \\
\hline \multirow{2}{*}{ Propriedade A } & $<70$ dias & 122 & 32 & $27,04^{\mathrm{a}}$ \\
\cline { 2 - 5 } & $>70$ dias & 106 & 9 & $7,54^{\mathrm{b}}$ \\
\cline { 2 - 5 } & Total & $\mathbf{2 2 8}$ & $\mathbf{4 1}$ & $\mathbf{1 8 , 0}$ \\
\hline \multirow{2}{*}{ Propriedade C } & $>70$ dias & 18 & 8 & $44,4^{\mathrm{a}}$ \\
\cline { 2 - 5 } & Total & $\mathbf{3 4}$ & 1 & $6,3^{\mathrm{b}}$ \\
\cline { 2 - 5 } & Totas & $\mathbf{3}$ & $\mathbf{2 6 , 5}$
\end{tabular}

ITC: intervalo tratamento colheita; Quartos: quartos mamários; Quartos R+: quartos mamários positivos para resíduo de antimicrobianos; \%: porcentagem de animais positivos para resíduo de antimicrobianos. ${ }^{a}$ Valores com as mesmas letras não diferem estatisticamente entre si pelo Teste de Fisher a 5\%.

O ITC foi calculado com base no período seco (em dias) (PS) e os dias desde o parto até a colheita das amostras (DPC) (PS + DPC) Entre as amostras colhidas na propriedade $A$ houve diferença estatística ( $P=0,0057)$ entre o ITC das amostras e a presença de resíduo, verificando-se que quanto maior o ITC menor a ocorrência de resíduos de antimicrobianos no leite $(10,4 \%)$. Na propriedade C verificou-se a mesma situação ocorrida na propriedade A, ou seja, quando o ITC foi menor que 70 dias a presença de resíduo de antimicrobianos foi maior (44,4\%), havendo diferença estatística significativa $(P=0,0189)$. Com base nos dados apresentados na Tabela 14 , observa-se que a presença de resíduo é inversamente proporcional ao ITC, de modo que quanto menor o período entre o tratamento e a liberação do leite, maior o risco de ocorrer resíduo no produto final. Resultado esperado, 
que confirma o já observado em relação à duração do período seco. Estes resultados reforçam a importância do ITC e recomenda-se o uso do teste para evitar a contaminação com resíduos na propriedade. Porém, se não for possível a execução do teste, para minimizar o risco de resíduo recomendarse-ia a liberação do leite somente 70 dias pós-tratamento, já que o ITC mais significativo para a presença de resíduo foi o menor que 70 dias (Tabela 14).

Assim, para se avaliar melhor o risco em decorrência do tratamento de vaca seca, em que se utiliza a terapia global e são usualmente tratados todos os quartos dos animais, verificou-se em relação aos animais tratados o número de quartos por animal que apresentavam resíduos de antimicrobianos. Nas Tabelas 15 e 16 estão apresentados os resultados referentes ao número de quartos positivos para resíduo de antimicrobiano por animal. Observou-se uma predominância de resíduo nos quatro quartos (58,5\%). Na Tabela 16 quando se comparou a presença de resíduo de antimicrobianos em 1 e 2 quartos com a presença de resíduo em 3 e 4 quartos verificou-se diferença estatística extremamente significativa $(P=0,0001)$.

Tabela 15 - Número de quartos com resíduo positivo para antimicrobianos por animal na propriedade A. Pirassununga, São Paulo. 2003

\begin{tabular}{cccccc}
\hline Grupos & Animais + & $\%$ & Quartos & Quartos R + & $\%$ \\
\hline 1 quarto & 4 & 26,6 & 15 & 4 & 9,75 \\
2 quartos & 2 & 13,3 & 8 & 4 & 9,75 \\
3 quartos & 3 & 20,0 & 12 & 9 & 21,9 \\
4 quartos & 6 & 40,0 & 24 & 24 & 58,5 \\
\hline Total & $\mathbf{1 5}$ & $\mathbf{1 0 0 , 0 0}$ & $\mathbf{5 9}$ & $\mathbf{4 1}$ & $\mathbf{1 0 0 , 0 0}$ \\
\hline
\end{tabular}

Animais +: animais positivos; Quartos: Quartos mamários; Quartos R+: quartos mamários positivos para resíduo de antimicrobiano; \%: porcentagem de quartos resíduo positivo. 
Tabela 16 - Número de quartos com resíduo positivo para antimicrobianos por animal na propriedade A. Pirassununga, São Paulo. 2003

\begin{tabular}{cccccc} 
Grupos & Animais + & $\%$ & Quartos & Quartos R + & $\%$ \\
\hline$\leq 2$ quartos & 6 & 40,0 & 23 & 8 & $19,51^{\mathrm{a}}$ \\
$\geq 3$ quartos & 9 & 60,0 & 36 & 33 & $80,48^{\mathrm{b}}$ \\
\hline Total & $\mathbf{1 5}$ & $\mathbf{1 0 0 , 0}$ & $\mathbf{5 9}$ & $\mathbf{4 1}$ & $\mathbf{1 0 0 , 0}$ \\
\hline
\end{tabular}

Animais +: animais positivos; Quartos: Quartos mamários; Quartos R+: quartos mamários positivos para resíduo de antimicrobiano; \%: porcentagem de quartos resíduo positivo. ${ }^{a}$ Valores com as mesmas letras não diferem estatisticamente entre si pelo Teste de Fisher a $5 \%$.

Os resultados apresentados na Tabela 16 evidenciam que a presença de resíduos de antimicrobianos no leite, no caso da terapia de secagem, ocorreu predominantemente em todos os quartos mamários e em pelo menos três deles, deste modo a possibilidade de contaminação dos tanques de pequena mistura pode ser maior. Uma vez que é fato bem conhecido que pequenas quantidades de resíduo podem comprometer grandes quantidades de leite. JONES \& SEYMOUR (1988), determinaram que uma vaca com 0,2 UI de penicilina/ml poderiam contaminar o leite de 40 vacas e ainda assim ser detectado na concentração de 0,005 Ul/ml. COELHO (2003) considerando a ocorrência de resíduo em um quarto comparado à ocorrência em três quartos não tratados observou maior ocorrência em três quartos, embora não tenha sido observada diferença estatisticamente significativa De acordo com o autor o acometimento de mais de um quarto com resíduo de antimicrobianos, resultaria em aumento no risco de contaminação do leite do animal como um todo e, conseqüentemente, aumentaria a risco de contaminação do leite de mistura.

Alguns autores demonstraram a importância do tratamento de mastite em vacas em lactação na contaminação do leite de pequena mistura. COSTA et al., (1999) estudaram 87 amostras de leite colhidas de tanques de expansão de diversas propriedades leiteiras, encontrando seis delas positivas para a presença de resíduos de antibióticos. Nos tanques positivos, 
os pesquisadores encontraram nível de mastite clínica no rebanho de $41,83 \%$, no qual era utilizado tratamento à base de gentamicina; como o teste foi positivo para a presença deste antibiótico, reforça-se a hipótese de que a origem dos resíduos é proveniente dos tratamentos de casos de mastite clínica.

Da mesma forma, os resultados obtidos no presente estudo demonstraram que o tratamento de vaca seca também pode contribuir para a ocorrência de resíduos detectáveis nos tanques resfriadores, na pequena e mesmo na grande mistura.

$\mathrm{Na}$ Figura 6 estão ilustrados os dados referentes ao número de quartos resíduo positivo para antimicrobianos por animal de acordo com 0 número de quartos mamários. De um total de 15 animais positivos para resíduo, 40\% apresentaram resíduo em todos os quartos mamários.

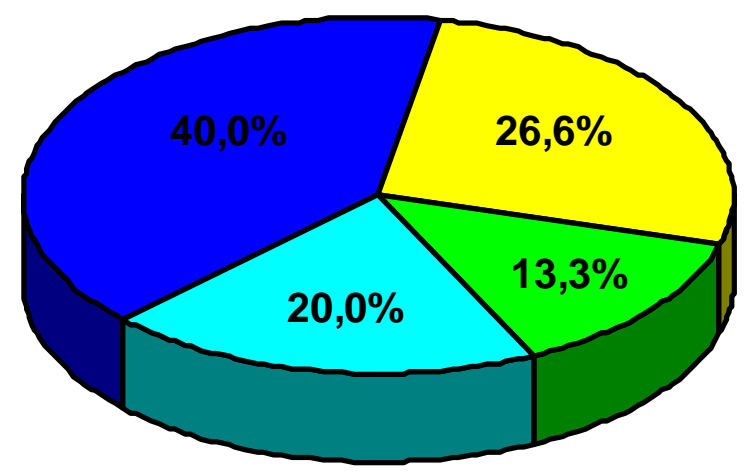

\section{$\square 1$ quarto $\square 2$ quartos $\square 3$ quartos $\square 4$ quartos}

Figura 6 - Porcentagem de animais positivos para resíduo de antimicrobianos de acordo com o número de quartos mamários. Pirassununga, São Paulo. 2003 
Com o objetivo de se avaliar medidas pragmáticas para se reduzir o risco de contaminação do leite com resíduos antimicrobianos em decorrência do tratamento de vaca seca foi realizada uma análise custo: benefício relacionando a utilização do período mínimo de descarte (71 dias) observado a partir dos resultados da Tabela 14 com a utilização do teste de triagem (Delvotest ${ }^{\circledR} \mathrm{SP}$ ) para detecção de resíduo de antimicrobianos. $\mathrm{Na}$ Tabela 17 estão apresentados os resultados da análise da relação custo: benefício. Calculou-se o ITL (intervalo tratamento limpeza do leite) considerando-se a duração do período seco (dias) de cada animal mais 10 dias que foi o período de aproveitamento do leite utilizado pela propriedade A (período de colostro). Posteriormente, realizou-se a subtração dos 71 dias considerados limiares de utilização do ITL de cada animal. Esse valor em dias correspondeu ao tempo de descarte do leite se fossem utilizados os 71 dias como padrão de descarte.

Incluiu-se na análise somente os animais pertencentes à propriedade A. Dos 27 animais que apresentaram ITC menor que 70 dias ( \pm 64 dias), 13 (48,14\%) deles entraram na análise custo: benefício por terem o leite aproveitado antes dos 71 dias considerados como limiar. Ressaltando que dos 13 animais, cinco $(38,46 \%)$ apresentaram excreção de resíduo de antimicrobiano no leite de consumo, e que três $(23,07 \%)$ deles excretaram resíduos de antimicrobianos nos quatro quartos.

Ao se utilizar como limiar de apoio o período mínimo de descarte observado nos resultados obtidos no presente estudo, em que houve uma significativa diminuição do risco de ocorrência de resíduo quando o intervalo tratamento colheita das amostras (ITC) foi maior que 70 dias, verificou-se, que não foi economicamente viável o descarte incondicional do leite até 71 dias pós-tratamento. Ao se adotar o descarte de 71 dias como padrão de segurança para a não presença de resíduo de antimicrobianos no leite, teríamos uma perda média diária de 400 litros de leite correspondendo a $\mathrm{R} \$$ 1.075,59 ou em dólares U\$372, 18, montante este que aproximadamente equivaleria ao custo do teste para treze animais durante 10 dias. Portanto a 
utilização do teste de triagem (Delvotest ${ }^{\circledR} \mathrm{SP}$ ) a campo de acordo com os dados apresentados da propriedade A é mais seguro e econômico, pois na verdade seria utilizado por cinco a 10 dias, sendo o restante utilizado por outros animais da propriedade. Além disso, cabe ressaltar que no presente caso os animais estariam apresentando resíduo positivo, se estivesse sendo utilizado como limiar de aproveitamento do leite para consumo o intervalo de 70 dias após terapia de secagem. 
Tabela 17 - Análise custo: benefício relacionando a utilização do período mínimo de descarte (71 dias) e a utilização do teste de triagem (Delvotest ${ }^{\circledR}$ SP). Pirassununga, São Paulo. 2003

\begin{tabular}{|c|c|c|c|c|c|c|}
\hline & Animal & $\begin{array}{l}\text { Produção média } \\
\text { de leite/kg/dia }\end{array}$ & ITL & 71 dias - ITL & R\$ litros leite & $\begin{array}{c}\text { R\$ custo } \\
\text { Delvotest }{ }^{\circledR} \mathrm{SP}\end{array}$ \\
\hline & 5499 & 32,2 & 69 & 2 & 28,98 & 22,88 \\
\hline & 5545 & 31,1 & 63 & 8 & 111,96 & 91,52 \\
\hline & 5547 & 24,7 & 66 & 5 & 55,58 & 57,20 \\
\hline & 5601 & 25,5 & 67 & 4 & 45,90 & 45,76 \\
\hline & 4442 & 27,0 & 54 & 17 & 206,55 & 194,48 \\
\hline & 4691 & 30,5 & 65 & 6 & 82,35 & 68,64 \\
\hline & 5174 & 34,9 & 62 & 9 & 141,35 & 102,96 \\
\hline & 5202 & 31,6 & 67 & 4 & 56,88 & 45,76 \\
\hline & 5283 & 28,4 & 64 & 7 & 89,46 & 80,08 \\
\hline & 5626 & 35,2 & 69 & 2 & 31,68 & 22,88 \\
\hline & 4860 & 34,8 & 67 & 4 & 62,64 & 45,76 \\
\hline & 5386 & 28,2 & 68 & 3 & 38,07 & 34,32 \\
\hline & 5683 & 34,5 & 63 & 8 & 124,20 & 91,52 \\
\hline Média & & 30,7 & 65 & 6 & 82,70 & 69,50 \\
\hline Total & 13 & 398,60 & & & 1075,59 & 906,65 \\
\hline
\end{tabular}

PS: período seco; ITL: intervalo tratamento limpeza do leite (PS + 10 dias); $R \$ /$ litros leite: Valor em reais perdidos em litros de leite. R\$ custo Delvotest: custo com a utilização do teste de triagem. Média anual do litro do leite tipo B (R\$ 0,42).Setembro 2002/ 2003 Fonte: FAESP. 
Ao ser realizada a análise custo: benefício concluiu-se que a utilização do teste quando comparado ao descarte de leite foi economicamente mais interessante. Portanto, com base nos dados apresentados neste estudo, se, o principal obstáculo para a execução do teste de triagem (Delvotest ${ }^{\circledR} \mathrm{SP}$ ) para a liberação do leite isento de resíduo de antimicrobiano, no pós-parto, for de ordem econômica (custo), deve-se lançar mão de uma análise custo: benefício relacionando o custo do leite descartado até o período de 70 dias.

De acordo com os resultados ilustrados na Figura 4, a média de quartos positivos para resíduo de antimicrobianos foi de 19,37\%. Este valor é considerável é deve ser utilizado como reforço de orientação de descarte do leite dos animais tratados no período seco. Outra alternativa, seria a utilização de testes de triagem para detecção de resíduos no leite antes da liberação do produto para consumo. Porém a validade desta alternativa recairá na disponibilidade de testes práticos e acurados para uso em propriedades leiteiras diretamente em amostras individuais.

Métodos de detecção como a cromatografia liquida de alto desempenho (HPLC), método analítico preciso utilizado como teste confirmatório da presença de resíduos no leite, foi utilizado por DENOBILE (2002) que, encontrou $11 \%$ de positividade para resíduos de oxitetraciclina em amostras de galões de leite recebidas em um laticínio de Minas Gerais. Contudo, o HPLC não é adequado para triagem, por ser uma técnica cara, exigir estrutura apropriada e pessoal especializado.

Os testes de inibição do crescimento bacteriano como o Delvotest ${ }^{\circledR}$ SP representam uma boa opção para uso como teste de triagem a campo para detecção de resíduos em amostras de leite de animais tratados. MCEWEN et al., (1991) relataram que para produtores do Canadá, os testes de detecção de resíduos são mais utilizados do que as recomendações de período de carência no momento da utilização do leite de 
uma vaca tratada. HILLERTON et al., (1999), afirma que o Delvotest ${ }^{\circledR}$ SP tem sido utilizado de forma crescente por produtores do Reino Unido.

Além desses autores citados acima, vários outros, nos últimos anos, têm indicado o uso de testes sensíveis e rápidos de detecção de resíduos de antimicrobianos no leite com o intuito de evitar prejuízos à saúde humana e a indústria de alimentos (ALTHAUS et al., 2001).

Para os objetivos deste trabalho, o uso do Delvotest ${ }^{\circledR} \mathrm{SP}$ mostrouse satisfatório. A ocorrência de resultados positivos neste teste pode servir como alerta aos produtores, de que, animais submetidos a terapia de secagem podem estar eliminando resíduo no leite além do período de carência e, o mais grave, este leite estar sendo incorporado ao tanque de pequena mistura junto ao de animais isentos de resíduos. Pois, torna-se muito difícil produzir leite ou mesmo outros produtos de origem animal totalmente isentos de resíduos de antimicrobianos. No entanto, as concentrações dos mesmos nos alimentos disponíveis para o consumidor, devem respeitar os limites estabelecidos internacionalmente (PALERMO, 2001). Embora as concentrações detectáveis pelo teste sejam menores que as estabelecidas, resultados positivos servem para orientar quanto a melhor medida a ser adotada. É preferível descartar a produção de um animal por mais alguns dias do que perder a produção de todos e a credibilidade junto ao mercado e colocar em risco a saúde do consumidor. 


\section{CONCLUSÕES}

As relevantes taxas de positividade de resíduos de antimicrobianos detectadas em animais tratados na interrupção da lactação, com medicamentos próprios para vaca seca, que constituíram os grupos experimentais, em três propriedades leiteiras demonstraram que o tratamento na secagem pode vir a constituir um risco, considerando a possibilidade de contaminação do leite de pequena mistura com resíduos de antimicrobianos. Ficou evidenciada a excreção dos medicamentos no leite, mesmo após o período de descarte recomendado, independente do tipo de manejo e práticas de ordenha utilizadas e do tipo de medicamento.

Entre os fatores pesquisados neste estudo, que poderiam interferir na ocorrência de resíduos no leite de animais tratados na secagem como, volume de produção na secagem e a produção média na lactação, observou-se que estes não influenciaram na ocorrência de resíduo de antimicrobianos no leite. Assim como, a presença de processo inflamatório, mastite, e/ou infecção nas glândulas mamárias não interferiram na ocorrência de resíduos no leite nos animais tratados na secagem, com medicamento para vaca seca.

Os resultados obtidos em relação à duração do período seco e os grupos de tratamento permitiram a constatação que a duração do período seco é realmente importante, e influencia na excreção de resíduos no leite, independentemente do medicamento utilizado. Foi demonstrado que o risco da presença de resíduo foi menor quando o período seco foi maior que 70 dias, demonstrando a importância da duração do referido período, na 
avaliação do risco de resíduo no leite de consumo, uma vez que, pode ocorrer a antecipação do parto.

O período seco preconizado como ideal por proporcionar à glândula mamária o tempo necessário para involução e se preparar para a colostrogênese e nova lactação (60 dias), não constitui garantia de isenção de resíduos no leite no pós-parto, uma vez que, 19,4\% dos quartos mamários tratados na secagem, com período seco entre 60 a 70 dias, apresentaram resíduos no leite, resultado que estatisticamente não diferiu do dos animais com período seco curto (60 dias).

Os resultados obtidos evidenciaram que a presença de resíduos no leite, ocorreu predominantemente em todos os quartos mamários $(58,5 \%)$ e em pelo menos três deles (21,9\%), aumentando assim a possibilidade de contaminação dos tanques de pequena mistura.

A presença de resíduos de antimicrobianos foi inversamente proporcional ao ITC, de modo que quanto menor o período entre 0 tratamento e a liberação do leite, maior o risco de ocorrer resíduos no produto final. É recomendável a utilização do teste de triagem nos animais no pós-parto, pois quando comparado ao descarte do leite até 71 dias assumidos como limiar de descarte, a utilização do teste foi economicamente mais interessante.

As informações técnicas da bula dos medicamentos sobre 0 período de descarte não se mostraram suficientes para assegurar à qualidade do leite. Os resultados obtidos devem ser levados em consideração quanto à orientação de descarte do leite dos animais tratados no período seco. Os animais submetidos à terapia da vaca seca devem ser testados no pós-parto até que estejam livres de resíduos de antimicrobianos no leite enviado para consumo. 
O uso do teste de triagem microbiológico (Delvotest ${ }^{\circledR} \mathrm{SP}$ ) mostrouse satisfatório para os objetivos deste trabalho.

Ao ser realizada a análise custo: benefício concluiu-se que a utilização do teste comparado ao descarte de leite foi economicamente mais interessante. 


\section{REFERÊNCIAS BIBLIOGRÁFICAS}

AERTS, M. M. L.; HOGENBOOM, A. C.; BRINKMAN, U. A. Analytical strategies for the screening of veterinary drugs and their residues in edible products. J. Chromatogr. B. Biom. Sci. Appl., Amsterdam, v. 667, n. 1, p. 1-40, 1995.

ALBUQUERQUE, L. M. B.; MELO, V. M. M.; MARTINS, S. C. S. Investigações sobre a presença de resíduos de antibióticos em leite comercializado em Fortaleza - CE - Brasil. Hig. Aliment. São Paulo, v. 10, n. 41, p. 29 - 32, 1996.

ALTERTHUM, F. Origem e natureza química dos principais agentes antibacterianos. In: TRABULSI, L. R.; ALTERTHUM, F.; GOMPERTZ, O. F.; CANDEIAS, J. A. N. Microbiologia. 3. ed. São Paulo: Atheneu, 1999. p. 87-92.

ALTHAUS, R. L.; MOLINA, M. P.; RODRIGUEZ, M; FERNANDEZ, N. Detection limits of beta-lactam antibiotics in ewe milk by penzym enzymatic test. J. Food Prot. v. 2; n. 64, n. 11, p. 1844-1847, 2001.

ANDRADE, J. R. A.; FIGUEIREDO, J. B.; LINS, J.L.F.H.A. Avaliação da liberação de resíduos de antibióticos no leite de vacas, pós medicação com penicilina e estreptomicina, em formulação aquosa e oleosa, coadjuvada pelo dimetilsulfóxido. Arq. Bras. Med. Vet. Zoot., v. 45, n. 4, p. 343-351, 1993.

ANDREW, S. M. Effect of composition of colostrums and transition milk from Holstein heifers on specifity rates of antibiotic residue tests. J. Dairy Sci., v. 84 , p. 100-106. 2001.

ANDREW, S. M.; FROBISH, R. A.; PAAPE, M. J.; MATURIN, L. J. Evaluation of selected antibiotic residue screening tests for milk from cows and examination of factors that affect the probability of false-positive outcomes.

J. Dairy Sci., v. 80, p. 3050-3057, 1997.

AURVAlLE, A. E. Presença de antibióticos no leite. Hora Vet., v. 1, p. n., 20-27, 1981. 
BARBERIO, A.; SIGNORINI, F. Antibiotici e sulfamidicini nel latte. Obiettivi Doc. Vet., Bologna, v. 17, n. 12, p. 29-36, 1996.

BARRAGRY, T. B. Bovine mastitis. In: Veterinary drug therapy. USA: Lea \& Febiger, 1994. p. 656-687.

BARROS, V. R. M.; PERCHES, E. M. C. Pesquisa de inibidores no leite tipo B distribuído ao consumo da grande São Paulo. Rev. Inst. Laticínios

Cândido Tostes, Juiz de Fora, v. 36, n. 216, p. 39-42, 1981.

BERRY, E. A.; HILLERTON, J. E. The effect of selective dry cow treatment on new intramammary infections. J. Dairy Sci, v. 85, n., p. $112-121,2002$.

BISHOP, J. R.; SENYK, G. F.; DUCAN, S. E. Detection of antibiotic/drug residues in milk and dairy products. In: MARSHALL, R. T. Standard methods for the examination of dairy products. $16 \mathrm{ed}$. Washington: American Public Health Association, 1992. cap. 12, p. 347-395.

BLOOD, D. C.; HENDERSON, J. A. Medicina veterinária. 4. ed. Rio de Janeiro: Guanabara Koogan, 1978. p. 871.

BRASIL. Leis, Decretos, etc. Portaria $n^{\circ} 8$, de 26 de junho de 1984. In: Balde Branco, São Paulo, v. 18, n. 238, p. 30-35, 1984. [Ministério da Agricultura, Secretaria Nacional de Defesa Agropecuária e Secretaria de Inspeção de Produto Animal definem normas técnicas e higiênico-sanitárias para a produção de leite tipo "B"].

BRITO, M.A.V.P. Normas internacionais e exigências do Codex Alimentarius e comparação entre blocos comerciais sobre a adoção de testes para detecção de resíduos de antibióticos no leite. In: Diagnóstico da qualidade do leite, impacto para a indústria e a questão dos resíduos de antibióticos. Juiz de Fora: Embrapa Gado de Leite; Epamig/CT/ILCT, 2003. 1 ed. 168 p.

BROWNING, J. W.; MEIN, G. A.; BRIGHTLING, P.; NICHOLLS, T. J.; BARTON, M. Strategies for mastitis control: Dry cow therapy. Aust. Vet. J., v. 71 , p. $179-181,1994$.

CAGIENARD, B. Mastitis prevalence and the selection of dry cow therapy programs in dairy herds. N. Z. Vet. J, n. 31, p. 30-31, 1983.

CANNON, R.Y.; HAWKINS, G.E.; WIGGINS, A.M. Duration of secretion of bacteriostatic drugs in milk. I. penicillin, following oral and parenteral administration. J. Dairy Sci., Savoy, v. 45, n. 6, p. 769-773, 1972.

CODEX MAXIMUM RESIDUE LIMITS FOR VETERINARY DRUGS IN FOODS. Adopted by the Codex Alimentarius Comission up to and including its Twenty second session (July 1997). FAO/WHO Food Standards Program. Viale delle Terme di Caracalla, Rome. Italy. 
COELHO, V.; COSTA, E. O. Avaliação da influência da intensidade de mastite do quarto tratado por via intramamária na ocorrência de resíduo de antimicrobianos no leite de quartos mamários não tratados. Rev.

NAPGAMA, São Paulo, v. 5, n. 1, p. 1-15. 2002

COELHO, V. R. P. Avaliação de resíduos de antimicrobianos no leite de quartos mamários não tratados de vacas com mastite tratadas por via intramamária. 2003102 p. Dissertação (Mestrado) - Faculdade de Zootecnia e Engenharia de Alimentos, USP.

CORASSIN, C.H.; OLIVEIRA, C. A. F. Aplicabilidade dos conjuntos para detecção de resíduos de antibióticos no leite em propriedades leiteiras. $\mathbf{O}$ Biológico, v. 62, n. 1, 2000.

COSTA, E. O. Importância da mastite na produção leiteira do país. Rev. Educ. Cont, São Paulo, v. 1, n.1, p. 3-9, 1998.

COSTA, E. O. Resíduos de antibióticos no leite: um risco à saúde do consumidor. Hig. Aliment, São Paulo, v. 10, n. 44, p. 15-17, 1996.

COSTA, E. O. Importância econômica da mastite infecciosa bovina. Rev. Fac. Med. Vet. Zootec. Univ. São Paulo, São Paulo, v. 15, n. 1, p. 21-26, 1991.

COSTA, E. O.; MELVILLE, P. A.; RIBEIRO, A. R.; WATANABE; E. T.; WHITE, C. R.; PARDO, R. B. Índices de mastite bovina clínica e subclínica nos Estados de São Paulo e Minas Gerais. Rev. Bras. Med. Vet., v. 17, n. 5, p. 215 - 217, 1995a.

COSTA, E. O.; RAIA, R. B.; GARINO JÚNIOR, F.; WATANABE, E. T.; RIBEIRO, A. R.; GROFF, M. R. Presença de resíduos de antibióticos no leite de pequena mistura de propriedades leiteiras. Rev. NAPGAMA, São Paulo, v. 2, n.1, p. 10-13, 1999.

COSTA, E.O. Uso de antimicrobianos na mastite. In: SPINOSA, H. S., GÓRNIAK,; S. L., BERNARDI, M. M. Farmacologia aplicada à medicina veterinária. 2. ed. Rio de Janeiro: Guanabara Koogan, 1999. cap. 42, p. 422-433.

COSTA, E. O.; MELVILLE, P. A.; VIANI, F. C.; PARDO, R. B.; WATANABE, $E$. T. Mastite subclínica influência do agente etiológico na intensidade do processo inflamatório. In: CONGRESSO INTERNACIONAL DE MEDICINA VETERINÁRIA EM LINGUA PORTUGUESA, 6., 1993, Salvador, BA. Anais...

COSTA, E. O.; SÁ, R.; PONCE; WATANABE, E. T; VALLE, C. R. Avaliação da terapia de mastite clínica: eficácia terapêutica medida em número de dias em tratamento. Rev. NAPGAMA. v. 2, n. 2, p. 10-14. 1999. 
COSTA, E.O.; RAIA, R.; WATANABE, E.T.; GARINO JÚNIOR, F.; COELHO, $\mathrm{V}$. Influência do tratamento intramamário de casos de mastite de bovinos em lactação em relação à presença de resíduos de antibióticos no leite dos quartos sadios não tratados. Rev. NAPGAMA, v. 3, n. 4, p. 14-17, 2000.

CULLOR J. S. Antibiotic residue tests for mammary gland secretions. Vet. Clin North Am. Food Anim. Pract., v. 9, n. 3, p. 609-620, 1993. Review.

CULLOR, J. S.; VAN EENENNAAM, A.; GARDNER, L.; PERANI, J.; DELLINGER, W.L.; SMITH, T.; THOMPSON, M.A.; PAYNE, L.; JENSEN, L.; GUTERBOCK, W.M. Performance of various tests used to screen antibiotics residues in milk samples from individual animals. J. Assoc. Off. Anal. Chem., v. 77, p. 862-870, 1994.

DENOBILE, M. Análise de resíduos dos antibioticos oxitetraciclina, tetraciclina, clortetraciclina e doxiciclina, em leite, por cromatografia líquida de alta eficiência. 2002. 121 p. Dissertação (Mestrado) Faculdade de Ciências Farmacêuticas, USP.

DUTT K. W.; EBERHART R. J.; WILSON R. A. In vitro growth of mastitis pathogens in mammary secretions of the dry and peripartum periods. $\mathbf{J}$. Dairy Sci, v. 69 n. 9, p. 2408 - 2415. 1986.

EBERHART, R.J. Management of dry cows to reduce mastitis. J. Dairy Sci, v. 69, p. $1721-1732,1986$.

EGAN J.; MEANEY, W. J. Persistence of detectable residues of penicillin and cloxacillin in normal and mastitic quarters following intramammary infusion. Vet. Rec., v. 116, n. 16, p. 436-438, 1985.

FAGUNDES, C. M.; MOLIN, L. Interferência dos resíduos de antibióticos no controle de qualidade do leite e derivados. Informe Agropecuário, v. 13, p. 24-30, 1988.

FAGUNDES, F.; ABREU, R.; VIEGAS, S. Principais efeitos de xenobióticos na glândula mamária da vaca: toxicologia do indivíduo. Universidade Técnica de Lisboa - Faculdade de Medicina Veterinária, Toxicologia, 2000.

FOOD AND DRUG ADMINISTRATION. Milk safety Branch Beta lactam testing under appendix N of the PMO. Dept. Health Human Serv., publ. Health Serv., FDA CFSAN: OFP: DPC: Milk Safety Branch, Washington, DC., 1999.

FOLEY, E. J.; STULZ, A. W.; LEE, S. W.; BYRNE, J. V. Studies on vehicles for sustaining penicillin levels in the bovine mammary gland. Am. J. Vet. Res., v. 10, n. 34, p. 66. 1949.

FONSECA, L. F. L.; SANTOS, M. V. Eficácia da gentamicina e cloxacilina para tratamento intramamário de vacas secas. Vet. Not. v. 6, n. 2, 2000. 
FUNK, D. A.; FREEMAN, A. E.; BERGER, P. J. Environmental and physiological factors affecting mastitis at drying off and post calving. J. Dairy Sci, v. 65, p. 1258 - 1268. 1982.

GARDNER, I. A.; CULLOR, J. S.; GALEY, F. D.; SISCHO, W.; SALMAN, M.; SLENNING, B.; ERB, H. N.; TYLER, J. W. Alternatives for validation of diagnostic assays used to detect antibiotic residues in milk. J. Am. Vet. Med. Assoc., v. 209, n. 1, p. 46-52. 1996.

GELLI, D. S.; JAKABI, M.; SOUZA, A. Inibidores microbianos em leite pasteurizado do comércio da cidade de São Paulo. Rev. Inst. Adolfo Lutz, São Paulo, v. 44, n. 1, p. 19 - 24, 1984.

GERALD, M. C. Sulfonamides and antibiotic. In: Pharmacology and introduction to drugs. Prentice, 1981. p. 561.

HASSAN, Z.; DANIEL, R. C. W.; O’BOYLE, D. O.; FROST, A. J. Effects of dry cow intramammary therapy on quarter infections in the dry period. Vet. Rec., v. 145, p. 634 - 639. 1999.

HAWKINS, G. E.; CANNON, R. Y.; PAAR, G. E. Concentration of penicillin in milk from noninfused quarters following infusion of one quarter. J. Dairy Sci., v. 45, p. 1020-22, 1962.

HILL, B. M.; SMALL, J. M. Antibiotic residues release at the beginning of lactation following dry cow therapy. N. Z. Vet. J., v. 33, p. 105, 1985.

HILLERTON, J. E.; HALLEY, B. I.; NEAVES, P.; ROSE, M. D. Detection of antimicrobial substances in individual cow and quarter milk samples using Delvotest microbial inhibitor tests. J. Dairy Sci, v. 82, p. 704 - 711. 1999.

HONKANEN-BUZALSKI, T.; REYBROECK, W. Antimicrobials. In: INTERNATIONAL DAIRY FEDERATION. Monograph on residues and contaminants in milk and milk products. Brussels: International Dairy Federation, 1997. cap. 4, p. 26-34.

HURLEY, W. L. Mammary gland involution and the dry period. Lactation Biology, ANSCI 308. University of Illinois, Urbana-Champaign, 2002.

JEKEL, J. F.; ELMORE, J.G.; KATZ, D.L. Epidemiologia, bioestatística e medicina preventiva. Porto Alegre: Artes Médicas Sul, 1999. 200 p.

JOHNSON, M. E.; MARTIN J. H.; BAKER, R. J.; PARSONS, J. G.

Persistence of antibiotics in milk from cows treated late in the dry period. $\mathbf{J}$. Dairy Sci., Savoy, v. 60, n. 10, p. 1655 - 1661, 1977.

JONES, G. M.; SEYMOUR, E. H. Cowside antibiotic residue testing. J. Dairy Sci., v. 71, n. 6 p. 1691-1699, 1988. 
KANG, J. H.; KONDO, F. Occurrence of false-positive results of inhibitor on milk samples using the Delvotest SP assay. J. Food Prot., v. 64, n. 8, p. 15.

KISER, J. S. Subtherapeutic uses of antibiotics and sulfonamides in animal agriculture. In: STEELE, J. H.; JUKES, T. H.; DUPONT, H. L.; CRAWFORD, L. M. eds. Antibiotics,sulfonamides, and public health. Boca Raton: CRC, 1984. v. 1, p. 81-107. (CRC Handbook Series in Zoonoses section D).

LEME, I. L.; FERREIRA, A.; PIGNATARI, A Resíduos de antibióticos em alimentos e suas implicações na saúde humana. Biológico, v. 61, n. 2, p. 99 - 104. São Paulo, 1999.

LOPES, L. T.; GANDARA, A. L. N., CRISTIANINI, M. Detecção de resíduos de antibióticos em leite comercializado na cidade de Campinas. Rev. Inst. Laticínios Cândido Tostes, Juiz de Fora, v. 53, n. 302, 303, p. 64-67, 1998.

MARTH, E. H.; ELLICKSON, B. E. Problems created by the presence of antibiotics in milk and milk products: a review. J. Milk Food Technol., Orange, v. 22, n. 7, p. 266 - 272, 1959.

McEWEN, S. A.; MEEK, A. H.; BLACK, W. D. A dairy farm survey of antibiotic treatment practices, residue control methods and associations with inhibitors in milk. J. Food Prot., Des Moines, v. 54, n. 6, p. 454-459, 1991.

MELLO F. A. Penicilina no leite de consumo na cidade de São Paulo e risco de sensibilização. Rev. PI. Med, São Paulo, v. 75, p. 21 - 34, 1969.

MERCER, H. D.; GELETA, J. N.; SCHULTZ, E. J.; WRIGHT, W. W. Milk-out rates for antibiotics in intramammary infusion products used in the treatment of bovine mastitis: relationship of somatic cell counts, milk production level, and drug vehicle. Am. J. Vet. Res., v. 31, n. 9, p. 1549-1560, 1970.

MIDIO, A. F.; MARTINS, D. I. Toxicologia de alimentos. São Paulo: Varela, 2000. p. 295.

MITCHELL, J. M.; GRIFFITHS, M. W.; McEWEN, S. A.; McNAB, W. B.; YEE, J. Antimicrobial drug residues in milk and meat: causes, concerns, prevalence, regulations, tests, and test performance. J. Food Prot., Des Moines, v. 61, n. 6, p. 742 - 756, 1998.

MORETAIN, J. P.; BOISSEAU, J. Elimination of aminoglycoside antibiotics in milk following intramammary administration. Vet. Q., Utrecht, v. 15, n. 3, p. 112 - 117, 1993.

MURRAY, P. R.; BARON, E. J.; PFALLER, M. A.; TENOVER, F. C.; YOLKEN, R. H. Manual of clinical microbiology. 7 ed. Washington, D.C.: American Society for Microbiology, 1999. 
NATZKE, R. P.; EVERETT, R. W.; BRAY, D. R. Effect of drying off practices on mastitis infection. J. Dairy Sci, v. 58, p. $1828-35,1975$.

NATZKE, R. P.; EVERETT, R. W.; GUTHRIE, J. F.; KEOWN, J. F. Mastitis control program: Effects on milk production. J. Dairy Sci. v. 55, p. 1256. 1972.

NICKERSON S. C.; BODDIE R. L.; OWENS W. E.; WATTS J. L. Effects of novel intramammary device models on incidence of mastitis after experimental challenge. J. Dairy Sci, v. 73, n. 10, p. 2774 - 2784, 1990.

NICKERSON, S. C. Imunological aspects of mammary involution. J. Dairy Sci, v. 72, p.1665 - 1678. 1989.

NICKERSON, S. C. O Papel da terapia no controle da mastite. In: Congresso PAN-AMERICANO DE QUALIDADE DO LEITE E CONTROLE DE MASTITE, 2., 2002, Ribeirão Preto. Anais... p. 85 - 98.

NICKERSON, S. C.; OWENS, W. E.; FOX, L. K.; SCHEIFINGER, C. C.; SHRYOCK, T. R.; SPIKE, T. E. Comparison of Tilmicosin and Cephapirin as a therapeutics for Staphylococcus aureus mastitis at dry-off. J. Dairy Sci, v. 82, p. $696-703,1999$.

NOUWS, J. F. M.; KUIPER, H.; VAN KLINGEREN, B.; KRUYSWIJK, P.G. Establishment of a microbiologically acceptable daily intake of antimicrobial drugs residues. Vet. Q., Utrecht, v. 16, n. 3, p. 152-156, 1994.

OLIVER, S. P.; DUBY, R. W.; TRITSCHLER, J. P. Residues in colostrum following antibiotic dry cow therapy. J. Dairy Sci, Savoy, v. 67, n. 12, p. 3081-3084, 1984.

OLIVER, S. P.; SORDILLO, L. M. Udder health in the periparturient period. J. Dairy Sci, v. 71, p. $2584-2589,1988$.

OLIVER, S. P.; LEWIS, M.J.; GILLESPIE, B.E.; DOWLEN, H.H. Influence of prepartum antibiotic therapy on intramammary infection in primigravid heifers during early lactation. J. Dairy Sci. v. 75, n. 2, p. 406 - 414. 1992.

OSTERAS, O.; AURSJO, J.; GRONNINGAESTER GJUL, G.; JORSTADA, A. Effect of dry cow therapy on subclinical mastitis - an evaluation of long action and short action intramammary. J. Med. Vet. B., n. 41, p. 529 - 40, 1994.

PAIGE, J.C. The issues of residues and human health. J. Am. Vet. Med. Assoc., Schaumburg, v. 23, n. 12, p. 1735 - 1736, 1998.

PARKINSON, T. J.; VERMUNT, J. J.; MERRALL, M. Comparative efficacy of three dry cow antibiotic formulations in spring calving New Zealand dairy cows. N. Z. Vet J., n. 48, p. $129-35,2000$. 
PEARSON, J. K. J. Further experiments in the use of penicillin in the prevention of $C$. pyogenes infection of the non-lactating bovine udder. Vet. Rec., v. 68, p. 215, 1951.

PHILPOT, W. N. Qualidade do leite e controle de mastite: passado, presente e futuro. In: Congresso PAN-AMERICANO DE QUALIDADE DO LEITE E CONTROLE DE MASTITE, 2., 2002. Ribeirão Preto - SP. Anais...

RADOSTITS, O. M.; LESLIE, W. B.; FETROW, J. Herd health. Food Anim. Product. Med, 1994 b.

RAIA, R. B.; COSTA, E. O.; GARINO JÚNIOR, F.; WATANABE, E. T.; THIERS, F. O.; GROFF, M. R. Estudo da persistência de eliminação de resíduos de antibióticos no leite após tratamento sistêmico e intramamário de mastite. Rev. NAPGAMA, São Paulo, v. 2, n. 1, p. 4 - 8, 1999.

RAIA, R. B. Jr. Influência da mastite na ocorrência de resíduos de antimicrobianos no leite. 2001. 78 p. Dissertação (Mestrado) - Faculdade de Ciências Farmacêuticas, USP,

REYBROECK, W. Evaluation of screening test for the detection of antimicrobial residues in milk. In: SYMPOSIUM ON RESIDUES OF ANTIMICROBIAL DRUGS AND OTHER INHIBITORS IN MILK, Kiel, 1995. Proceedings. International Dairy Federation, 1995a. p. 182-186.

RUEGG, P. L.; TABONE, T. J. The relationship between antibiotic residue violations and somatic cell counts in Wisconsin Dairy herds. J. Dairy Sci. v. 83 , p. 2805 - 2809. 2000.

SANDHOLM, M.; KAARTNEN, L.; PYORALA, S. Bovine mastitis: why does antibiotic therapy not always work? An overeview. J. Vet. Pharmacol. Ther, v. 13 , p. $248-260,1990$.

SCHALM, O. W.; NOORLANDER, D. O. Experimental and observation lading to development of California mastitis test. J. Am. Vet. Med. Assoc., Schaumburg, v. 130, n. 5, p. 199 - 204, 1957.

SEYMOUR, E. H.; JONES, G. M.; McGILLIARD, M. L. Comparisons of onfarm screening tests for detection of antibiotic residues. J. Dairy Sci., v. 71, p. 539-544, 1988.

SMITH, B. P. Tratado de medicina interna de grandes animais:

moléstias de eqüinos, bovinos, ovinos e caprinos. v. 2, p. $1056-1057$. 1994.

SMITH, K. L.; TODHUNTER, D. A.; SCHOENBERGER, P. S. Environmental mastitis: cause, prevalence, prevention. J. Dairy Sci. v. 67, p. 367. 1985.

SPINOSA, H. S. Antibióticos: tetraciclinas, cloranfenicol e análogos. In: H. S.; GORNIAK, S. L.; BERNARDI, M. M. Farmacologia aplicada à 
medicina veterinária. 2. ed. Rio de Janeiro: Guanabara Koogan, 1999. p. 333-336.

STATISTICAL ANALYSIS SYSTEMS FOR PERSONAL COMPUTERS. 1990-1993. GRAPHPAD INSTAT software.

STOBBERINGH, E. E.; BOGAARD, A. E. Spread of antibiotic resistence from food animals to man. Acta Vet. Scand. Vanloese, v. 93, p. 47-52, 2000. (supplement).

SUNDLOF, S. F. Drug and chemical residues in livestock. Vet. Clin. North Am. Food Anim. Pract., Philadelphia, v. 5, n. 2, p. 411 - 449, 1989.

TADDIO, S. J. Drugs of choice for pregnant woman, in maternal-fetal toxicidad a clinican's guide. 2 ed. rev. New York: Marcel Dekker, 1994. p. $115-28$.

TORTORRA, G.; FUNKE, B. R; CASE, C. L. Drogas antimicrobianas. In: TORTORA, G.; FUNKE, B. R.; CASE, C. L. Microbiologia. 6. ed. Porto Alegre: Artes Médicas Sul, 2000. p. 531-552.

WATANABE, E. T. Avaliação do uso de antibióticos por via intramamária e sistêmica no tratamento de mastite clínica em vacas em lactação e subclínica na interrupção da lactação. 1999. 121 p. Dissertação (Mestrado) - Instituto de Ciências Biomédicas - USP.

ZIV, G.; GORDIN, S.; BECHAR, M. S. Mode of antibiotics from treated to nontreated quarters in dairy cows. Am. J. Vet. Res., v. 35, n. 5, p. 643-647, 1974. 